\title{
Exosomes: A Key Piece in Asthmatic Inflammation
}

\author{
José A. Cañas ${ }^{1,2} \mathbb{D}$, José M. Rodrigo-Muñoz ${ }^{1,2} \mathbb{D}$, Marta Gil-Martínez ${ }^{1} \mathbb{D}$, Beatriz Sastre $^{1,2, * \mathbb{D}}$ and \\ Victoria del Pozo 1,2,3,*(D)
}

check for

updates

Citation: Cañas, J.A.;

Rodrigo-Muñoz, J.M.; Gil-Martínez,

M.; Sastre, B.; del Pozo, V. Exosomes:

A Key Piece in Asthmatic

Inflammation. Int. J. Mol. Sci. 2021,

22, 963. https://

doi.org/10.3390/ijms22020963

Received: 21 December 2020

Accepted: 18 January 2021

Published: 19 January 2021

Publisher's Note: MDPI stays neutral with regard to jurisdictional claims in published maps and institutional affiliations.

Copyright: (c) 2021 by the authors. Licensee MDPI, Basel, Switzerland. This article is an open access article distributed under the terms and conditions of the Creative Commons Attribution (CC BY) license (https:// creativecommons.org/licenses/by/ $4.0 /)$.
1 Immunoallergy Laboratory, Immunology Department, Instituto de Investigación Sanitaria Fundación Jiménez Díaz (IIS-FJD), Avenida Reyes Católicos, 2, 28040 Madrid, Spain; jose.canas@fjd.es (J.A.C.); jose.rodrigom@quironsalud.es (J.M.R.-M.); marta.gilm@quironsalud.es (M.G.-M.)

2 CIBER de Enfermedades Respiratorias (CIBERES), Av. de Monforte de Lemos, 3-5, 28029 Madrid, Spain

3 Faculty of Medicine, Universidad Autónoma de Madrid, 28029 Madrid, Spain

* Correspondence: bssastre@fjd.es (B.S.); vpozo@fjd.es (V.d.P.)

\begin{abstract}
Asthma is a chronic disease of the airways that has an important inflammatory component. Multiple cells are implicated in asthma pathogenesis (lymphocytes, eosinophils, mast cells, basophils, neutrophils), releasing a wide variety of cytokines. These cells can exert their inflammatory functions throughout extracellular vesicles (EVs), which are small vesicles released by donor cells into the extracellular microenvironment that can be taken up by recipient cells. Depending on their size, EVs can be classified as microvesicles, exosomes, or apoptotic bodies. EVs are heterogeneous spherical structures secreted by almost all cell types. One of their main functions is to act as transporters of a wide range of molecules, such as proteins, lipids, and microRNAs (miRNAs), which are singlestranded RNAs of approximately 22 nucleotides in length. Therefore, exosomes could influence several physiological and pathological processes, including those involved in asthma. They can be detected in multiple cell types and biofluids, providing a wealth of information about the processes that take account in a pathological scenario. This review thus summarizes the most recent insights concerning the role of exosomes from different sources (several cell populations and biofluids) in one of the most prevalent respiratory diseases, asthma.
\end{abstract}

Keywords: asthma; extracellular vesicles; exosomes; biofluids; eosinophils; miRNAs

\section{Introduction}

Asthma is a heterogeneous airway disease with a complex inflammatory component. This disease is characterized by a dysregulated process that contributes to its maintenance, progression, and perpetuation. In this process, both resident cells (e.g., epithelial and endothelial cells, fibroblasts) and inflammatory cells (e.g., eosinophils, mast cells, T cells) interact with each other and secrete soluble mediators of inflammation, which drive disease pathogenesis [1-3].

In recent decades, extracellular vesicles (EVs) have emerged as essential actors in intercellular communication through cell-to-cell contact or by shuttling different molecules, such as nucleic acids, lipids, and proteins. Exosomes can, therefore, significantly affect target cell function, resulting in the development of a pathological state [4]. For example, exosomes have been studied most extensively in association with different inflammatory pathologies, such as cancer and other infectious diseases [5,6], and also in asthma [7-12] (Figure 1). 


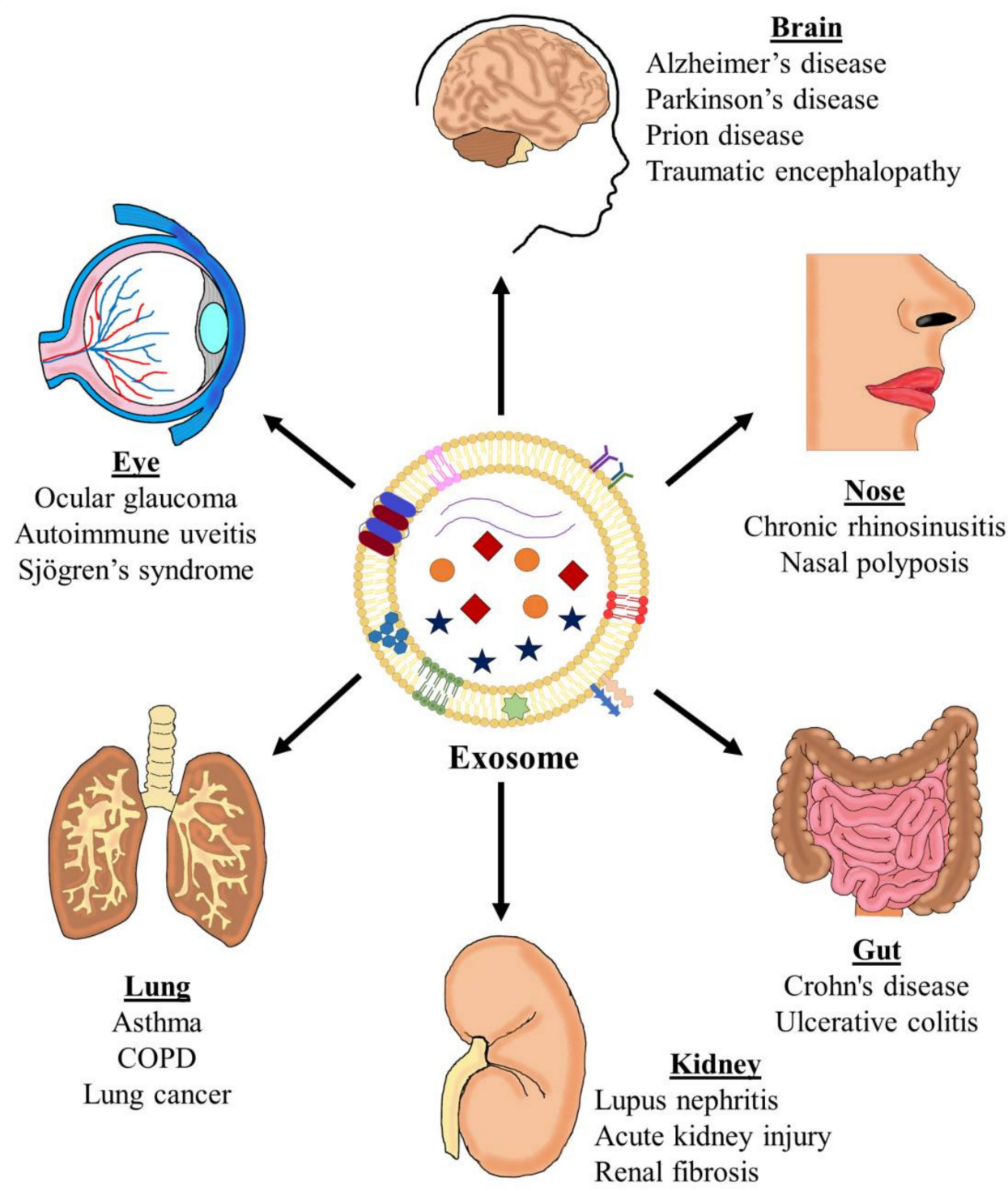

Figure 1. The implication of exosomes in inflammatory diseases. Exosomes have been described as modulators of different inflammatory diseases in different organs, including the brain (Alzheimer's and Parkinson's diseases), eye (ocular glaucoma), nose (chronic rhinosinusitis, nasal polyposis), lung (asthma, chronic obstructive pulmonary disease (COPD), and lung cancer), gut (inflammatory bowel disease), and kidney (lupus nephritis, acute kidney injury, and renal fibrosis). Figures inside and in the surface of the exosome represent some of their components. Inside: blue star: lipid mediators; exosome biogenesis proteins; violet lines: nucleic acids. In the surface: blue and red elipses: tetraspanins; green, red and pink structures: ceramide, phosphatidylserine, and sphingomyelin; violet and green: major histocompatibility complex (MHC)-I and -II, blue structure: integrin; pink structure; adhesion molecule; blue hexagons: cholesterol; green star: Rab proteins.

In this review, we summarize current advances regarding the role of exosomes in the pathogenesis of asthmatic inflammation.

\section{Extracellular Vesicles: Biogenesis and Composition}

EVs are small vesicles released by donor cells into the bloodstream and body fluids, which can be taken up by recipient cells [13]. Though discovered decades ago, it has only recently become apparent that EVs play an important role in cell-to-cell (intercellular) communication and in the secretion of small soluble molecules into the extracellular environment (the secretome) as well as direct cell-cell contact [14].

EVs are heterogeneous spherical structures secreted into the extracellular microenvironment by almost all cells, both prokaryotic and eukaryotic [15]. Suspended in the 
aqueous nucleus or associated with the lipid casing is a wide repertoire of molecules contained and carried by EVs; these molecules include nucleic acids (DNA, mRNA, and small non-coding RNAs, such as microRNAs (miRNAs)), lipids, and proteins (cytokines, receptors, or their ligands) [16-18]. These vesicles are surrounded by a lipid membrane (phospholipid bilayer) enclosing the materials contained within, which are immersed in a small organelle-free cytosol $[19,20]$; this phospholipid bilayer creates a stable internal environment for biologically active components by protecting them from enzymatic degradation during transit throughout the extracellular environment [21].

The ability of EVs to carry a variety of nucleic acids, lipids, and proteins and, consequently, transfer this cargo to recipient cells influences various physiological and pathophysiological functions in these cells, causing EVs to have a significant impact on the phenotype of recipient cells [22]. For this phenotypic effect to occur, once EVs are released outside the donor cell, recipient cells can take these vesicles and trigger signaling events on the cell surface or be internalized by the cells, either through endocytosis or membrane fusion, which releases their contents inside the target cells, where they cause functional effects [23]. Among other diseases, EVs are implicated in inflammatory lung disorders, including asthma [7], chronic obstructive pulmonary disease (COPD) [24], and sarcoidosis [25], and maybe a universal spreader of inflammation.

It should be noted that there have been discrepancies in the literature regarding the classification of EVs. Some studies divide them into two main subgroups: exosomes, which are vesicles released from multivesicular bodies (MVBs) by exocytosis, and ectosomes, vesicles assembled and released by the plasmatic membrane (PM) [26]. However, more recent studies categorize EVs according to their size, biogenesis, and release; these categories include large apoptotic bodies (>1 $\mathrm{m}$ ); microvesicles (MVs), also called cellular ectosomes or microparticles, which comprise the intermediate fraction (200-1000 nm); exosomes, the smallest fraction (30-150 nm) [27] (Figure 2).

\subsection{Apoptotic Bodies}

Apoptosis, or "programmed" cell death, is an important mechanism of cell death in both normal and cancerous cells [28]. Whereas exosomes and MVs are secreted during normal cellular processes, apoptotic bodies are vesicles that are released only from cells undergoing this process of cell death (apoptotic cells) as products of apoptotic cell disassembly [29].

Apoptotic cells undergo a series of morphological changes, such as condensation of nuclear chromatin, fragmentation and degradation of internucleosomal DNA, nuclear and cellular organelle rupture (endoplasmic reticulum, Golgi and mitochondria, with the consequent release of cytochrome c), proteolytic cleavage of the cytoskeleton and focal adhesion complexes, phosphatidylserine (PS) externalization, alteration of key survival functions, blebbing of the PM, cell shrinkage, and commitment to the apoptotic phenotype. These changes ultimately package cell content in vesicles called apoptotic bodies (also called "apoptotic bullae" or "apoptotic vesicles"), ranging from 1-5 $\mu \mathrm{m}$ in diameter [30-32]. The term "apoptotic body" was coined by Kerr in 1972 [33].

Irrespective of the route to caspase activation, all pathways lead to the activation of the major effector caspases $(3,6$, and 7$)$, and these enzymes carry out much of the proteolysis seen during the apoptotic process [34].

During normal development, most apoptotic bodies are phagocytosed by macrophages and thus eliminated locally [35]. Clearance is mediated by specific interactions between certain molecules of the apoptotic cells' membrane-due to specific changes in its composition-and recognition receptors on the phagocytic cells [36]. Translocation of PS to the external face of the PM, one of the hallmarks of apoptosis, and its subsequent binding to annexin $\mathrm{V}$, recognized by phagocyte surface receptors, results in the digestion of "cell debris" [37]. In addition to this, oxidation of surface molecules, another well-characterized $\mathrm{PM}$ alteration, creates binding sites for thrombospondin (TSP) or complement protein C3b, also recognized by phagocyte receptors [36,38]. 
Therefore, the main protein markers of apoptotic bodies include, along with histones, annexin V, TSP, and C3b $[39,40]$. A notable distinction between apoptotic bodies and the other two major EV groups is that they also contain fragmented DNA and cellular organelles from their host cell [41].

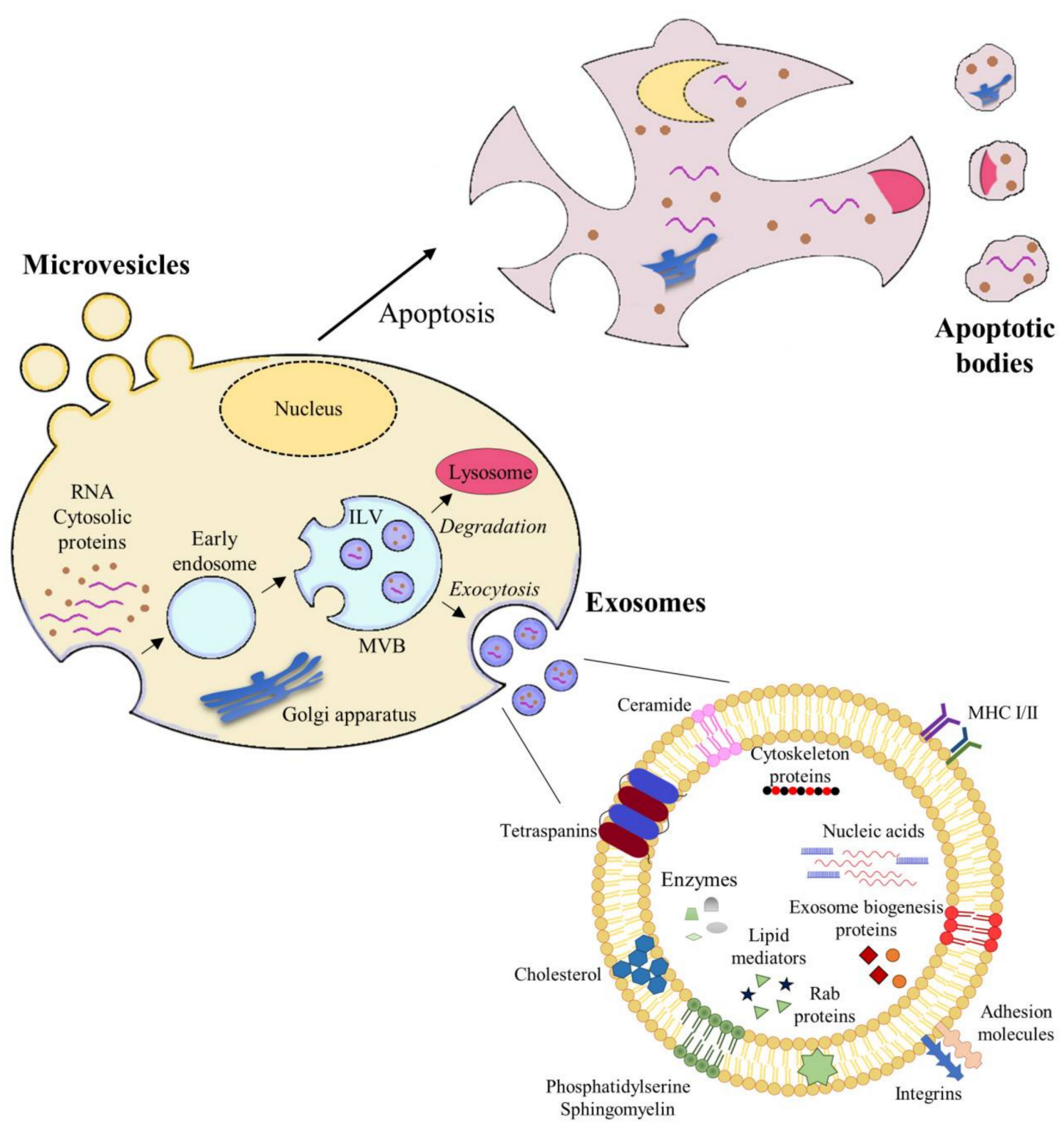

Figure 2. Extracellular vesicle biogenesis and exosome structure. Cells release several types of extracellular vesicles (EVs), including apoptotic bodies, microvesicles, and exosomes. Apoptotic bodies are large vesicles (1000-5000 nm in diameter), which are released from apoptotic cells. Microvesicles are medium-large EVs (100 nm to $1 \mu \mathrm{m}$ in diameter), which originate directly from the cell membrane, followed by fission and release towards the extracellular space. Exosomes are small vesicles (30-150 nm) derived from endosomes. Maturation of early endosomes into late endosomes produces invaginations called intraluminal vesicles (ILVs). This endosome with ILVs is denominated multivesicular bodies (MVBs). These MVBs are able to fuse with lysosomes and degrade their cargo or with the plasma membrane to release ILVs towards the extracellular space. Exosomes are formed by a double lipid membrane and contain cytoskeletal proteins, tetraspanins, integrins, and adhesion molecules, and other proteins that reflect their endosomal biogenesis. 


\subsection{Microvesicles (MVs)}

Throughout the scientific literature, MVs have also been referred to as ectosomes and microparticles, among other names [42]. Ectosomes were first defined by Stein and Luzio, who observed ectocytosis and shedding of vesicles from the PM in stimulated neutrophils [43]. MVs are formed from the outward budding of the PM of the host cell surface [44]. The process that leads to MV generation starts with the formation of outward buds at specific sites of the membrane, followed by fission and subsequent release of the vesicle into the extracellular space [45].

MV biogenesis involves vertical trafficking of molecular cargo to the PM, molecular rearrangements, and the use of contractile actin-myosin machinery on the cell surface to allow for vesicle detachment [46]. The PM undergoes changes in lipid and protein composition and in $\mathrm{Ca}^{2+}$ levels, resulting in the recruitment and activation of calcium-dependent enzymes that are involved in disassembling the cytoskeleton and the exchange of lipids between the inner and outer leaflets of the membrane bilayer to maintain membrane asymmetry, thereby favoring budding and membrane abscission [47-49]. The asymmetric distribution of the PM is tightly regulated by aminophospholipid translocases [50]. In particular, externalization of the phospholipid PS occurs, which normally resides exclusively in the inner monoleaflet, which induces the formation of MVs [51]. Proteins that promote cytoskeleton contraction through actin-myosin interactions have been implicated in vesicle formation and cleavage [52]. Both cargo content and MV shedding are firmly regulated by several small GTPases, including members of the ADP-rybosilation factor (ARF; ARF1 and ARF6), Rab, and Rho (Rac1 and RhoA) families [53-56].

MVs are shed from the PM through direct outward budding, which defines their diameters and molecular compositions [57]. MVs are distinct from other EVs owing to the expressions of phospholipids and proteins on their surfaces [58]. Weerheim et al. determined that circulating MV membranes next to PS (3.63\%) predominantly contained phosphatidylcholine $(59.2 \%)$, sphingomyelin $(20.6 \%)$, and also phosphatidylethanolamine (9.4\%) [59]. Several studies have highlighted the fact that MVs contain a diverse population of proteins, including matrix metalloproteinases, glycoproteins, integrins, receptors, and cytoskeletal components; the main markers used to detect MVs are integrins, selectins, and cluster of differentiation (CD)40 [60-63]. The content of MVs also can include nucleic acids, particularly mRNA and miRNAs [64].

An important role in cargo selection seems to be that of the ARF6-regulated recycling pathway, which can regulate the inclusion of proteins, such as major histocompatibility complex (MHC) class I, $\beta_{1}$ integrin receptors, vesicle-associated membrane protein 3 (VAMP3), and membrane type 1 matrix metalloproteinase (MT1MMP) [55].

\subsection{Exosomes}

The term exosome was coined by. Rose Johnstone to advance understanding of the biologic process underlying the transformation from a reticulocyte to a mature erythrocyte [65]. This nomenclature was adopted for vesicles released during reticulocyte differentiation as a consequence of MVB fusion with the PM [66].

Exosomes range in size from $30 \mathrm{~nm}$ to $150 \mathrm{~nm}$ and are formed within the cell by the inward invagination of late endosome membranes to form what has come to be known as MVBs [44]. The late endosome becomes a so-called MVB, comprising multiple vesicles, intraluminal vesicles (ILVs), and thus incorporating components of the cytosol [67]. These MVBs can either fuse with the lysosome if the content is destined for degradation or fuse with the PM, resulting in the release of the ILVs as exosomes into the extracellular space (Figure 2) [68].

ILV formation inside MVBs first requires reorganization of the endosome membrane, which is highly enriched in tetraspanins; second, the process must involve recruitment of the endosomal sorting complexes required for transport (ESCRTs) [69,70]. Four different ESCRTs have been designated, i.e., ESCRT 0, I, II, and III [71]. Although the ESCRT pathway is generally thought to be the main driver of exosomal biogenesis, the existence of 
ESCRT-independent exosome biogenesis has been shown [72], as seen in the involvement of sphingomyelinase activity, the implication of other lipids-cholesterol and phosphatidic acid - and the formation of these vesicles promoted by syntenin [73-75].

The Soluble NSF Attachment Protein Receptor (SNARE) protein complex has been implicated in the fusion of the MVBs with the PM, and the $\mathrm{Ca}^{2+}$-regulated vesicle-associated membrane protein 7 (VAMP7), a SNARE complex member, has been described as stimulating the release of acetylcholinesterase-containing exosomes [76]. Finally, in the release of ILVs as exosomes, a number of Rab GTPases, including RAB7, RAB11, RAB27A/B, and RAB35, are recognized as playing an important role [77].

Exosomes are typically composed of a lipid bilayer membrane and contain a luminal cargo that comprises proteins, DNA, RNA, peptides derived from lipids, surrounded by a lipid bilayer membrane (Figure 2). The phospholipid membrane contains lipids that bear the signature of the PM of the cell of origin, with high levels of cholesterol, sphingomyelin, ceramide, and detergent-resistant membrane domains, called lipid rafts $[78,79]$. The luminal content of exosomes predominantly includes cytosolic proteins derived from the donor cell [80]. Since exosomes originate from endosomes, proteins involved in MVB formation (e.g., Alix and tumor susceptibility geen [TSG]101), membrane transport, and fusion (e.g., annexins, flotillins, GTPases) are distinguishing proteins present on exosomes [81]. Another distinguishing feature of exosomes is the presence of tetraspanins, including CD9, CD63, CD81, and CD82 [82]. Other proteins present in exosomes include adhesion (e.g., integrins), antigen presentation (MHC class molecules), and heat shock proteins (HSP70, HSP90) [81].

Furthermore, many studies have shown the presence of nucleic acid cargo, which may include a variety of non-coding RNAs, including miRNAs and long non-coding RNA [82]. Other than different RNA species, exosomes also contain chromosomal and mitochondrial DNAs [83].

\section{Exosomes in Biofluids in Asthmatic Inflammation}

Asthma complexity and its multifactorial character have been mentioned previously. Given this complexity, when defining the disease, not only the cellular component is important, but also the soluble inflammatory microenvironment plays a key role in the development and evolution of asthmatic pathology.

Development of bodily fluid-extracted biomarkers would be a highly useful tool, as these would eliminate the need to employ more invasive procedures and tissue samples; however, a disadvantage is that fluids from the organism contain large amounts of aggregates and other components that pose contamination issue during isolation [84]. Pure EV isolation is mandatory to ensure that the results obtained are not confounded by contamination by viruses or other components [85]. Thus, there are multiple methods for the purification of EVs, based on the different characteristics of them. The methods present several advantages and disadvantages, and it is necessary to select the most appropriate method according to the specific characteristics of each sample (Table 1).

In the context of asthma, bronchoalveolar lavage and induced sputum will be the more representative biofluids of the lung environment, providing overall knowledge of the inflammatory composition of this specific microenvironment. 
Table 1. Methods to isolate extracellular vesicles (EVs).

\begin{tabular}{|c|c|c|c|}
\hline Method & Methodology & Advantages/Disadvantages & Ref. \\
\hline Differential centrifugation & $\begin{array}{l}\text { * Stepwise manner. } \\
* \text { Sequential centrifugations, increasing the centrifugation speed. }\end{array}$ & $\begin{array}{l}\text { - Low cost, large quantities of the solution, absence of chemicals. } \\
\text { - Complexity, equipment (ultracentrifuge), and efficiency depend } \\
\text { on the type of rotor. }\end{array}$ & {$[39,86,87]$} \\
\hline Chromatography & $\begin{array}{l}\text { * Filtration through columns of porous smaller than EV of } \\
\text { interest }\end{array}$ & $\begin{array}{l}\text { - Rapid isolation, preservation of vesicle integrity. } \\
\text { - Limitations of sample volume, specialized equipment, } \\
\text { complexity. }\end{array}$ & {$[90,91]$} \\
\hline Ultrafiltration & $\begin{array}{l}\text { * Use of porous membranes to trap molecules with a specific size } \\
\text { through successive steps to obtain EVs with the desired size. } \\
{ }^{*} \text { Based on size and mass. }\end{array}$ & $\begin{array}{l}\text { - Simplicity, processing of many samples, lack of limitations on } \\
\text { sample volume. } \\
\text { - Sample contamination by proteins, loss of sample by filter } \\
\text { plugging }\end{array}$ & {$[92,93]$} \\
\hline Precipitation by chemicals & $\begin{array}{l}\text { * Use of organic solvents, polyethylene glycol, sodium acetate, or } \\
\text { protamine. }\end{array}$ & $\begin{array}{l}\text { - Relatively quick, able to be used in a wide range of samples. } \\
\text { - Contamination with non-EV proteins, retention of chemicals, } \\
\text { long processing time. }\end{array}$ & [94-97] \\
\hline Precipitation by polymers & $\begin{array}{l}\text { * Commercial kits } \\
{ }^{*} \text { Use of super hydrophilic polymers solutions, or PEGs. } \\
\text { * Diminished the solubility of EVs and generation of a pellet } \\
\text { precipitate. }\end{array}$ & $\begin{array}{l}\text { - Simple procedure, no need for additional equipment. } \\
\text { - Usually costly, not be good for large samples of EVs, high } \\
\text { concentration of impurities. }\end{array}$ & {$[39,90]$} \\
\hline $\begin{array}{l}\text { Precipitation by protein surfaces } \\
\text { (immunoassay) }\end{array}$ & $\begin{array}{l}{ }^{*} \text { Immunoprecipitation. } \\
{ }^{*} \text { Magnetic beads coated with antibodies for common EV surface } \\
\text { proteins, such as CD63, CD9, and CD8. } \\
{ }^{*} \text { Use after a centrifugation method for isolation. }\end{array}$ & $\begin{array}{l}\text { - High purity and selectivity. } \\
\text { - High cost, selectivity may be too high, difficulties for } \\
\text { detachment antibodies and to analyze the intact vesicles. }\end{array}$ & {$[98,99]$} \\
\hline
\end{tabular}




\subsection{Bronchoalveolar Lavage Fluid}

In bronchoalveolar lavage fluid (BALF), a widely used sample obtained from the lung, the main limitation to EV purification is the small volume of the specimen, creating a need to use an excellent purification method, for which there are several optimized techniques [100]. In this type of sample, the MVs $(100-400 \mathrm{~nm})$ are the main type of EVs, followed by exosomes [101].

Several studies have analyzed the effect of BALF-derived EV on the pathogenesis of asthma, using different approaches to evaluate this, from animal models to proteomics.

The first studies carried out by Prado et al. $[102,103]$ focused on allergic murine models and demonstrated that BALF-derived exosomes inhibited specific immunoglobulin-(Ig)E and IgG1 - and that pre-treatment with these exosomes also inhibited Th2 cytokines. In related findings, Shin et al. [104], using a murine model, observed that inhaled lipopolysaccharide (LPS)-induced BALF-derived EVs play an important role in the intercellular communication that takes place during the immune response and its possible dysfunction after inhaled LPS-containing allergens.

In human samples, the first studies with BALF exosomes [105] explored the phenotypic and functional characteristics of BALF-derived exosomes in asthma compared to others obtained from healthy subjects, simultaneously observing leukotriene (LT) biosynthetic capacity of these exosomes from asthmatic patients to leukotriene (LT) C4 (LTC 4$)$ and interleukin (IL)-8 release. BALF exosomes in the asthma context, therefore, might contribute to subclinical inflammation in airway epithelium. Recently, a study using mass spectrometry reported significant differences in the lipid composition of EVs between four groups studied (healthy, secondhand smoke (SHS)-exposed healthy, asthmatics, and SHS-exposed asthmatics), revealing that ceramides, ceramide-phosphates, phosphatidylglycerols, and sphingomyelins were altered based on pathology, and their abundance aided in discriminating between study groups [106]. Indeed, several studies about the influence of cigarette smoke on exosome production and composition have been developed [107]. These results point to a significant role for BALF-derived EVs, acting as elements to transfer active lipids. Besides lipid content, other manuscripts, such as the Rollet-Cohen et al. study [108], using a proteomic approach, demonstrated the different protein content of BALF exosomes from three different lung diseases (cystic fibrosis, primary ciliary dyskinesia, and asthma), observing different proinflammatory profiles.

EVs are an important transport element for multiple molecules, including miRNAs. Some asthmatic and allergic murine models have evaluated the role of these structures in the development and evolution of this disease, observing that some exert a proinflammatory effect, such as miR-21 [109], while another like miR-224, in an asthma murine model aggravated by particulate matter 2.5 (PM2.5), decreases the inflammation by targeting Toll-like receptor (TLR) 2 and the reduction of Th17 inflammatory cells [110]. Moreover, Gon et al. [111] observed a higher amount of EVs in the airways in a house dust mite (HDM) murine model vs. control mice, identifying significant changes in the expression of 139 miRNAs from EVs and 175 miRNAs from lung tissues; a computational analysis revealed that 31 genes, including IL13 and IL5RA, are putative targets of these miRNAs found to be up-regulated in EVs [111].

Several studies have been performed in humans, showing a relation of exosomes' content of BALF with different clinical characteristics of the disease (Table 2), as the studies of Levänen [112] and Francisco-García [113]. 
Table 2. Summary of data concerning miRNAs detected in different biofluids linked to clinical parameters.

\begin{tabular}{|c|c|c|c|c|}
\hline Sample & Groups of Study & Results & Function/Effects & Ref \\
\hline Bronchoalveolar lavage fluid & $\begin{array}{l}\text { * Healthy and asthma individuals. } \\
\text { * Severe asthma patients. }\end{array}$ & $\begin{array}{l}\text { - } 24 \text { miRNAs differentially expressed from } 894 \text { miRNAs } \\
\text { evaluated. } \\
\text { - Prominent role of the let-7 family, especially miR-200. } \\
\text { - Deficient loading of miRNAs into their nanovesicles. These } \\
\text { miRNAs generated a network. }\end{array}$ & $\begin{array}{l}\text { - Downregulated in asthma group. Correlated with airway } \\
\text { remodeling. } \\
\text { - MiRNAs network associated with worsened lung function } \\
\text { and increased eosinophilic and neutrophilic inflammation. }\end{array}$ & $\begin{array}{l}{[112]} \\
{[113]}\end{array}$ \\
\hline Induced sputum & $\begin{array}{l}{ }^{*} \text { Healthy, mild-to-moderate and severe } \\
\text { asthma patients. } \\
{ }^{*} \text { Healthy and asthmatic patients. }\end{array}$ & $\begin{array}{l}\text { - Higher expression of miR-629-3p, miR-223-3p, miR-142-3p. } \\
\text { - Used epithelium, sputum, and plasma samples. } \\
\text { - In sputum, miR-221-3p correlates with eosinophils. } \\
\text { - Increase of miR-221-3p after } 4 \text { weeks of inhaled } \\
\text { corticosteroids compared to baseline. }\end{array}$ & $\begin{array}{l}\text { - Related to neutrophilic inflammation. } \\
\text { - Biomarker for airway eosinophilic inflammation; moreover, } \\
\text { being an element of airway inflammation improve after } \\
\text { treatment. }\end{array}$ & $\begin{array}{l}{[114]} \\
{[115]}\end{array}$ \\
\hline \multirow[t]{2}{*}{ Serum and/or plasma } & $\begin{array}{l}\text { * Asthmatic and healthy children. The } \\
\text { author sub-classified asthmatics children } \\
\text { into two groups, steroid-resistant and } \\
\text { steroid-sensitive. }\end{array}$ & $\begin{array}{l}\text { - Serum miR-21 level was increased in asthmatics vs. healthy } \\
\text { as well as in steroid-resistant patients compared to } \\
\text { steroid-sensitive patients. } \\
\text { - Positive correlation with blood and sputum eosinophil count } \\
\text { and inversely correlated with } \mathrm{FEV}_{1} \text {. } \\
\text { - Higher levels of miR-155 in plasma from asthmatic patients } \\
\text { and decreased levels of let-7a. }\end{array}$ & - MiR-21 could be a severity biomarker in asthma pathology. & [116] \\
\hline & ${ }^{*}$ Asthmatic and healthy children. & $\begin{array}{l}\text { - MiR- } 155 \text { presented a direct correlation with IL-13 levels and } \\
\text { an inverse correlation with FEV } 1 \text { and FVC. Let-7a correlated } \\
\text { positively with FEV } \text { F }_{1} \text { and FVC and inversely with IL-13 } \\
\text { expression. }\end{array}$ & $\begin{array}{l}\text { - MiR-155 and let-7a showed opposite results. MiR-155 could } \\
\text { be a biomarker of worsened lung function. }\end{array}$ & [117] \\
\hline
\end{tabular}


Studies have even been conducted in the pediatric asthma population. Shi et al. [122] observed a higher expression of miR-26a, miR-146a, and miR-31 in BALF of asthmatic children compared to controls. In a manuscript from the same year, miRNA-let $7 \mathrm{a}, 7 \mathrm{~b}$, and 7c detected in BALF from asthmatic children were identified as biomarkers of asthma [123].

\subsection{Induced Sputum}

Nowadays, induced sputum is one of the biofluids with increasing applications, focusing on asthma research and diagnosis, as it is easily obtained and has a direct relationship with airway inflammatory status.

Globally, manuscripts about sputum in asthma have focused on miRNA contents and their functions in this disease, although in 2017, the first study was published in which exosomes of induced sputum were isolated from asthmatic patients [124].

In the same year, Maes et al. published their manuscript related to several miRNAs, severe and neutrophilic asthma [114] (Table 2); the group led by Liu found that miR-125b was downregulated in sputum from patients with eosinophilic asthma. They demonstrated an indirect role of this miRNA on the inhibition of goblet cell differentiation, being a potential candidate for improving therapeutic approaches for asthma [125]. In addition, miR-145 and miR-338 were also found together in several respiratory diseases like asthma, COPD, and asthma-COPD overlap syndrome (ACOS) [126]. Both miRNAs were more increased in supernatant than in peripheral blood; miR-145 was only elevated in asthma, while miR-338 was increased in all obstructive lung diseases analyzed. For both miRNAs, levels were higher in the supernatant of COPD and asthma patients than in controls. A study of cell-free sputum supernatants from allergic asthmatic patients showed a statistically significant reduction in the level of miR-155 compared to healthy subjects [127], leading the authors to suggest that the heterogeneous composition of sputum results in alternative miRNA expression levels. The authors further hypothesized that this downregulation of miR-155 might be linked to a lymphocyte dysfunction in the airways of these subjects. In a similar trend, miR-146a was lower in allergic asthmatics than in healthy controls. Recently, using sputum, an RNA sequencing and complex bioinformatics analysis showed a miRNA network associated with specific phenotypes of asthma [128]. Gomez et al. found a sputum miRNA network (particularly containing "nely" network module) associated with sputum neutrophilia and lymphocytosis, with a reduction of forced expiratory volume in $1 \mathrm{~s}\left(\mathrm{FEV}_{1}\right)$ percentage predicted and a decrease of the quality of life, just like increased hospitalizations in the previous year. This network was made up of 12 miRNAs, and among them, miR-223-3p was the miRNA most closely correlated with these clinical features, and these results were similar to those obtained previously by another group [114]. Moreover, classifying patients by their expression of "nely" miRNAs, the results revealed that subjects with asthma and these miRNAs had reduced $\mathrm{FEV}_{1} \%$ predicted both before and after bronchodilation in a scenario with similar inhaled corticosteroids (ICS) doses; also, miR-223-3p expression levels were correlated with multiple features of severe asthma, bronchodilator response, and fractional exhaled nitric oxide (FeNO) levels [128].

\subsection{Serum and Plasma}

In the study of EVs in asthma pathology, other approaches may use serum or plasma. Just as in previous biofluids commented, EVs are the main transport elements of miRNAs and are resistant to RNase degradation.

Multiple miRNAs have been identified as playing a role in asthma pathogenesis and response to treatment, both in the adult and pediatric populations, which were measured in serum or plasma samples [129].

MiR-21 is one of the most widely studied miRNAs in several pathologies, including asthma, and it has been linked to several clinical parameters as eosinophil count, as in the manuscript of Elbehidy and colleagues [116] (Table 2). In a recent paper, another group confirmed elevated serum levels of miR-21 in patients with eosinophilic asthma compared to sera levels in healthy individuals [130]. A positive correlation was found 
between serum miR-21 and IL-4, confirming the role of this miRNA in Th2 activation and asthma pathogenesis. The authors also observed increased miR-155 expression in asthmatic sera; however, the absence of correlation with both IL-4 and miR-21 expressions indicated that the effect of both miRNAs on asthma pathogenesis is likely mediated by different pathways.

Prior to this manuscript, other groups demonstrated the role of miR-155 in both adult and childhood asthma pathology, like a manuscript of Karam and collaborators [117] in relation to miR-155 and let-7a (Table 2); similar results about let-7a have been previously detected [131]. Elevated levels of miR-155 in the serum of asthmatic children compared with those of the control group were observed by Liu and collaborators [132], who found a close association with the levels of indoor $\mathrm{PM}_{2.5}$ in the asthma group but not in the control group. Recently, this miRNA was considered an intracellular pro-inflammatory mediator of asthma, and the antagonism of miR-155-5p has been postulated to have corticosteroidlike effects on the treatment of asthma in a childhood asthmatic population [133]. As a result, miR-155 decreases glucocorticoid (GC)-induced NF- $k B$ trans-repression. These authors predicted an improvement in lung function in the ICS treatment group with the combination of two miRNAs, that is, miR-155-5p and miR-532-5p, through a logistic regression model. In this line, Weidner and collaborators [134] found that miR-155 and miR146 were differentially expressed in allergic asthmatic patients compared to a non-allergic asthma population, and this increase was observed when the subjects were using ICS. The two miRNAs share target genes involved in response to GCs and leukocyte regulation. Moreover, miR-223 and miR-374 showed a significant change in the non-allergic asthma group when blood eosinophil count was used as a classification parameter. These authors postulated that a combination of circulating miRNAs could be a tool that would aid in classifying asthmatic patients.

Similar to miR-155, other miRNAs, such as miR-16, may function as a biomarker to predict responses to therapy in asthma [118] (Table 2). In certain cases, miRNA expression levels differ based on asthma endotypes, such as neutrophilic or eosinophilic asthma [119,120] (Table 2), showing associations with different clinical parameters. In addition to miRNA functionality as predictors of treatment response, a recent paper from Fan and co-worker [135] demonstrated the role of miR-203a-3p in mechanisms linked to the development of classical asthma features. The authors of the study demonstrated that miR-203a-3p was able to modulate transforming growth factor-beta (TGF- $\beta$ )1-induced epithelial-mesenchymal transition (EMT) through the Smad3 pathway. Yang et al. observed that miR-448-5p could affect TGF- $\beta 1$-mediated EMT and pulmonary fibrosis in asthma [136]. Following this mechanistic approach, Du et al. [137] observed that miR-98-5p could be implicated in the development of bronchial asthma in a pediatric population through the decrease of the IL-13 expression.

However, due to the complex relationship between miRNAs and genes, not all miRNAs can be used as biomarkers. One solution to this problem may be to use combinations of several miRNAs or a specific miRNA profile, which may result in good sensitivity, specificity, and positive and negative predictive values. Our group, basing our work on an eosinophil miRNA profile, created a logistic regression model with three miRNAs (miR-185$5 p$, miR-144-5p, and miR-1246) to better discriminate between asthma and healthy subjects; indeed, a Random Forest model created with miR-185-5p, miR-320a, and miR-144-5p was capable of separating healthy individuals from asthma patients and, within the disease group, classified each one in terms of disease severity [138]. Findings from our study suggest that the miRNA profile detected in eosinophils could be used as a diagnostic tool for asthma in serum and rank patients according to severity. In this line, some manuscripts about the prediction of exacerbations have been published [121] (Table 2). However, miRNAs contained in EVs are not the only good element to characterize asthma or predict disease course or treatment response. This year, several manuscripts have probed the importance of serum EVs analysis to understand other parameters that can exert an effect on asthma pathology. Lee et al. [139] used EVs from the serum of healthy and asthmatic 
individuals to extract DNA and study, by means of metagenomic analysis, the microbial composition and its relation to clinical characteristics of asthma. The authors obtained a bacterial composition that was significantly different between the two groups, creating a diagnostic model based on these differences with good predictive values (sensitivity: 0.92, specificity: 0.93). They, therefore, demonstrated the important role of the microbiome as a potential diagnostic marker of asthma, employing the serum. Kim et al. [140] focused their attention on bacterial EVs IgG antibody titers in serum, observing that in asthma and COPD patients, these titers were higher than in healthy controls, postulating that these values could be used as a diagnostic tool for lung disease.

As we have previously reported, there are studies analyzing the relationship between exosome production and various clinical parameters; however, the effect of age on exosome synthesis is a field yet to be developed, with some existing data concluding that EVs in plasma decrease with age [141].

All these results and data demonstrate that more research is needed to elucidate the roles that EVs and their contents, such as miRNAs, can play as biomarkers or predictors in the therapeutic response in asthma. Likewise, studies comparing EVs with other biomarkers that are already well characterized and available are needed.

\section{Exosomes from Eosinophils as Key Cells in Asthma}

Eosinophils are innate immune cells that have been widely associated with asthma pathophysiology [142]. This end-stage granulocyte derived from bone-marrow progenitor cells can affect lung physiology, the inflammatory focus in asthma, driven by diverse mediators [143]. The development, survival, and migration of eosinophils are due to actions of key cytokines and chemokines of type 2 (T2) immune response as IL-5, IL-4, RANTES (C-C chemokine ligand [CCL]5), and eotaxins (eotaxin-1 (CCL11), eotaxin-2 (CCL24), and eotaxin-3 (CCL26)), which are recognized by receptors (IL-5R $\alpha$ and C-C chemokine receptor [CCR]3) in the eosinophils, activating their functions [144-146].

The array of T2 cytokines, which induces eosinophils' recruitment and activation in asthma pathophysiology, is released by diverse cell types, including Th2 lymphocytes [147] and type 2 innate lymphoid cells (ILC2s) [148]. ILC2s are the first source of T2 cytokines when recruited by alarmins released by the lung epithelium (IL-25, IL-33, and thymic stromal lymphopoietin (TSLP)) after an allergen encounter [149,150].

Eosinophils recruited to the lungs are triggers of asthma hallmarks, which include airway remodeling (increase in smooth muscle mass and epithelial desquamation), mucus hypersecretion, and local inflammation. This array of immuno-structural regulations is done by the eosinophil granule proteins, which contain variable enzymes, compounds, and cytokines. Their granules and vesicles can be studied by electron microscopy $[151,152]$ and contain receptors for eotaxin, interferon-gamma (IFN $\gamma$ ), and CCR3, making them autonomously competent organelles capable of releasing their contents upon ligand binding [153] by exocytosis, vesicle-mediated piecemeal degranulation [154-156], or by eosinophil cytolysis [157]. The composition of protein granules consists of enzymes that cause epithelial damage, such as eosinophil cationic protein (ECP), eosinophil peroxidase (EPO), eosinophil-derived neurotoxin (EDN), or major basic protein (MBP) [158-160].

Eosinophils are able to release other molecules involved in remodeling, including metalloproteinases like matrix metalloproteinase 9 (MMP-9) [161], molecules affecting inflammation, such as nitric oxide (NO), lipid mediators like LTs (promote autocrine eosinophil migration and survival) [162], and reactive oxygen species (ROS) that contribute to airway injury [163]. Furthermore, eosinophils have the capacity of rapidly releasing very diverse preformed cytokines both from T1 and T2 immune pathways (IL-4, IL-6, IL-10, IL-12, IL-13, IFN $\gamma$, and tumor necrosis factor-alpha (TNF $\alpha$ )), due to their storage in granules and vesicles, which facilitates fast release in response to different stimuli, such as vesicle transported-IL-4 or eotaxin [158,164-168].

Equally important are the eosinophil extracellular DNA traps (EET) (from the nuclear or mitochondrial origin), consisting of the release of DNA from the cell as a physical 
net with which to capture pathogens [169]. Sometimes, this liberation of extracellular DNA traps causes eosinophil death (EETosis) [170,171]. In fact, eosinophils from severe eosinophilic asthma have displayed an increased percentage of eosinophil extracellular traps when treated with LPS and IL-5. These traps can autocrinally promote eosinophil degranulation, inducing further inflammation in the airways of severe asthmatics [172].

In the last few years, a new eosinophil derivate has been studied due to its role in asthmatic disease: the exosomes. The road to the discovery of eosinophils' capability to release exosomes began in 2002 when the tetraspanin CD63 was described inside eosinophils as being involved in piecemeal degranulation after stimulation with IFN $\gamma$ [173]. A few years later, in 2009, Akuthota et al. showed that CD9, another exosomal marker, was expressed on the surface of eosinophils and that it colocalized with MHC class II in the detergentresistant membrane microdomains (DRMs) after stimulation with granulocyte-macrophage colony-stimulating factor (GM-CSF). These two proteins give eosinophils the capacity to function as antigen-presenting cells [174].

Given that the multivesicular body marker CD63 is inside eosinophils, that eosinophils express CD9 on their surfaces, and that other cells of the immune system are capable of releasing exosomes [7], it is not unreasonable to consider that eosinophils are able to secrete them, something which was speculated back in 2012 [175].

The theory was confirmed in 2015 when Mazzeo et al. [11] described the presence of MVBs inside eosinophils. Using antibodies against the endosomal marker CD63 and the multivesicular body marker lysobisphosphatidic acid (LBPA), the authors were able to detect colocalization of both proteins in eosinophilic granules by confocal microscopy and transmission electron microscopy (TEM). Interestingly, the addition of IFN $\gamma$, a well-known stimulator of granule mobilization, caused enhancement of CD63 and LBPA expressions in the PM. This confirmed vesicle fusion from the cytoplasm to the membrane to release their contents. This mobilization was observed by time-lapse fluorescence microscopy and flow cytometry, showing how the cytoplasmic levels of CD63 and LBPA decreased upon IFN $\gamma$ stimulation.

To characterize exosomes from eosinophils, the authors purified exosomes from eosinophils of asthmatic or healthy subjects. Validation of exosomal markers was performed by Western blot (Alix, CD63, and CD9) and TEM (Alix, CD63), and exosomes were measured by nanoparticle tracking analysis (NTA). Results showed that exosomes indeed expressed specific markers and had the expected exosomal size. Furthermore, NTA showed that non-stimulated eosinophils from asthmatics were able to produce higher amounts of exosomes when compared to eosinophils from healthy sources, while IFN $\gamma$ stimulation yielded no differences for the secretion of exosomes of asthmatics compared to healthy individuals. Finally, using Western blotting, the authors confirmed the presence of the eosinophil enzymes EPO, MBP, and ECP in exosomes derived from eosinophils, and the quantity of these proteins was similar between exosomes from asthmatic and healthy subjects. Together, these results confirmed the capacity of eosinophils to release exosomes, further showing that exosome secretion is higher in eosinophils from asthmatics, which may be related to the direct correlation found in another study between the EV concentration in the asthmatic airway and peripheral eosinophilia, meaning that the exosomes may play a role in asthma pathology [11].

A year later, an independent research group corroborated Mazzeo et al.'s results. Using techniques, such as TEM, nanoscale flow cytometry, and protein electrophoresis, the authors were able to detect the exosomes released by eosinophils, confirming their size and presence of CD63 and CD9 [176]. Using TEM, they observed an increase in MVB release after treatment with CCL11, and even higher with TNF $\alpha$, compared to untreated individuals. Additionally, stimulation increased the number of MVB-producing eosinophils from $50 \%$ to $90-100 \%$, while MVBs released by the effect of TNF $\alpha$ were smaller in size than those released following administration of CCL11 or when untreated. The results of the study also highlighted the importance of marker selection for MVBs, around 50\% of MVBs were stained for CD63 and only 15\% for CD9, so seemingly CD63 might be a 
better marker for MVBs. Finally, the authors confirmed MVB formation after stimulation by annexin-V and reported that MBVs were not apoptotic bodies, as evidenced by TUNEL assay in confocal microscopy [176].

Experimental procedures performed by Cañas et al. showed that exosomes released from eosinophils were taken up by eosinophils themselves. Exosomes from asthmatics were able to autocrinally increase the production of NO (colorimetric assay), while exosomes isolated from both healthy and asthmatic subjects induced ROS synthesis (flow cytometry intracellular staining) [177]. Proteomic mass spectrometry analysis was carried out in order to determine exosome contents, revealing that the contents were similar to those usually secreted by eosinophils, including ECP, MBP, EPO, asthma-related proteins like periostin [178], and others related to migration, adhesion, cell signaling, redox, inflammation, or metabolism; no differences were found to reflect the asthmatic or healthy origin of these contents. Basal eosinophil apoptosis was initially higher in eosinophils from healthy subjects, and the addition of exosomes isolated from healthy or asthmatic subjects did not cause any effect. Nonetheless, adhesion, chemotaxis, and chemokinesis were increased by exosomes obtained from asthmatics. This enhancement of adhesion was accompanied by upregulation of intercellular adhesion molecule (ICAM)-1 and integrin $\alpha_{2}$ on the surfaces of eosinophils treated with asthmatic exosomes, augmenting eosinophil inflammation $[179,180]$.

All these results confirmed that exosomes derived from asthmatics' eosinophils could upregulate eosinophils' own functions, probably due to their protein content quantity and due to the enhanced capacity of asthmatic eosinophils to release exosomes [11,177].

When exosomes derived from asthmatic or healthy eosinophils were taken up by airway structural cells (small airway epithelial cells (SAECs) and bronchial smooth muscle cells (BSMCs)), several changes in their behavior were induced [12]. Specifically, wound healing capacity was delayed, while an increase in apoptosis (measured by annexin$\mathrm{V}$ and TUNEL assay) was observed in SAEC cultured after $24 \mathrm{~h}$ with exosomes from asthmatics. Additionally, gene expression of the TNF, CCL26, and POSTN was upregulated by the addition of asthmatic exosomes at different time points, depending on whether there was an epithelial wound or not. Many of these phenotype changes result from the effect of asthmatic exosomes on epithelial phosphorylated protein kinase B (pAKT) and phosphorilated signal transducer and activator of transcription (pSTAT3)measured by Western Blot, with a reduction of both proteins at $24 \mathrm{~h}$ and enhancement at $48 \mathrm{~h}$.

In contrast, BSMCs treated with asthmatic exosomes showed increased proliferation at $72 \mathrm{~h}$ due to an enhancement of phosphorylated extracellular regulated kinase (pERK) protein levels and underwent an increase in the expression of the proangiogenic and chemotactic genes VEGFA and CCR3.

All these results demonstrate the role of exosomes from asthmatic eosinophils as key molecules, contributing to structural lung-cell activation and airway remodeling [12]. Therefore, we can conclude that exosomes from eosinophils are indeed autonomous molecules that are able to modulate and enhance the pathophysiology of asthma acting on eosinophils and also on structural lung cells alongside the rest of the compounds released by these immune cells (Figure 3). 


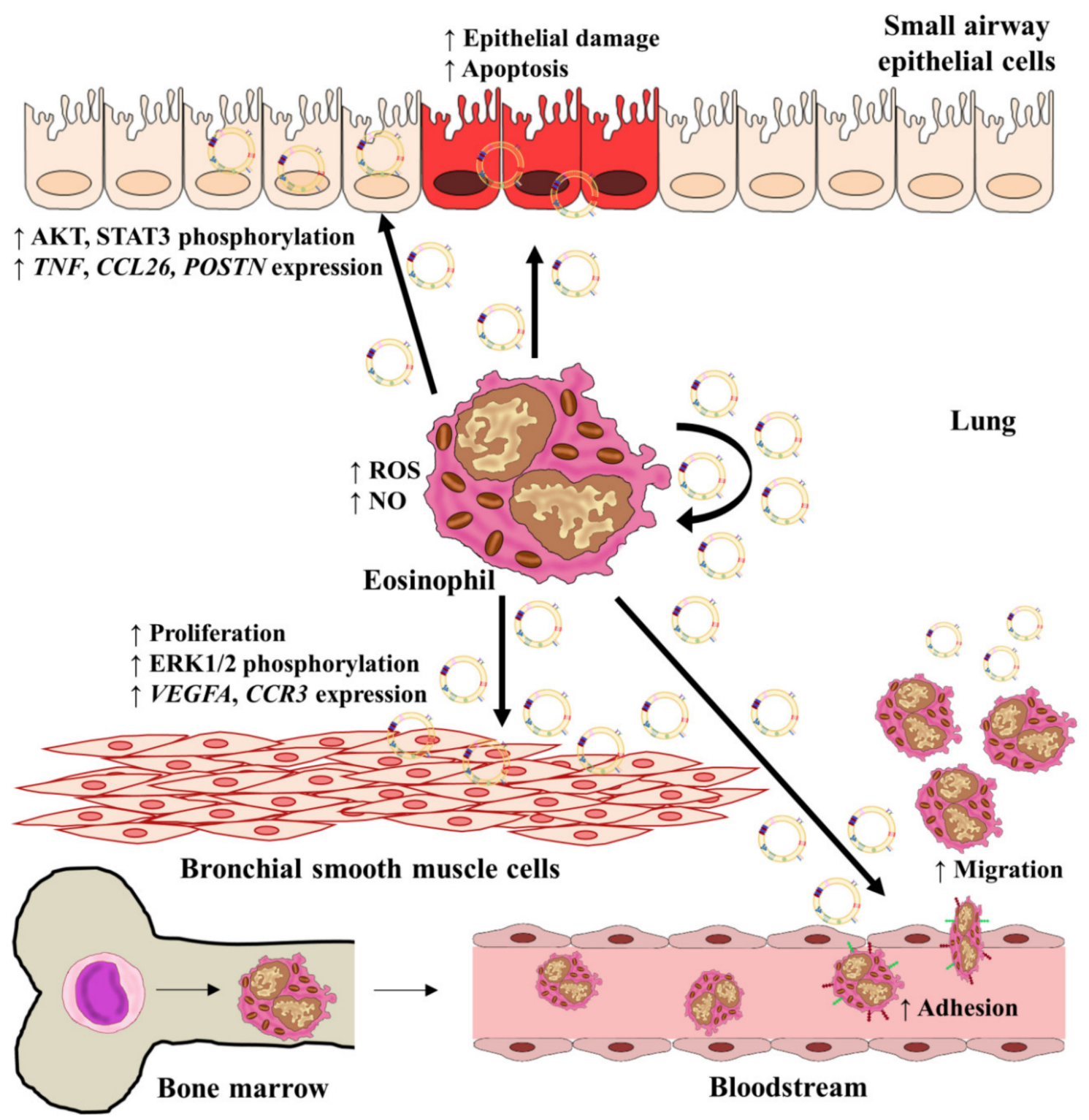

Figure 3. Specific roles of eosinophil-derived exosomes in asthmatic inflammation. Exosomes released by eosinophils are able to alter several functions associated with asthmatic pathology on both eosinophils themselves and structural lung cells, such as small airway epithelial cells and smooth bronchial muscle cells. Exosomes can increase eosinophil adhesion and migration and the release of ROS and NO, contributing to tissue damage. Moreover, exosomes augment BSMC proliferation and SAEC injury, increase the expression of several genes implicated in asthmatic inflammation and remodeling (TNF, POSTN, CCL26, POSTN, VEGFA, and CCR3), and alter some pathways implicated in asthma, including MAPK and JAK/STAT. Abbreviations. AKT: protein kinase B; STAT3: signal transducer and activator of transcription 3; TNF: tumor necrosis factor; CCL26: C-C chemokine ligand 26; POSTN: periostin; ROS: reactive oxygen species; NO: nitric oxide; ERK: extracellular regulated kinase; VEGFA: vascular endothelial growth factor A; CCR3: C-C chemokine receptor 3.

\section{Exosomes from Other Cellular Populations Implicated in Asthma Pathology}

As remarked previously, exosomes can be found in multiple localizations and can be released by a variety of cell types. This fact draws a resemblance between exosomes and their origin cells in terms of proteins and nucleic acids. Airway inflammation in asthma pathogenesis is driven by several effector cells, including $\mathrm{T}$ and B lymphocytes, macrophages, mast cells, eosinophils, and structural lung cells (epithelial and smooth muscle cells) [181]. These cells exert their functions either directly or indirectly, via exosomes and EVs [4]. This part of the review, therefore, focuses on the most recent findings related 
to exosomes released by the principal effector cells that participate in inflammation of the asthmatic disease.

Peripheral blood mononuclear cells (PBMCs) have a round nucleus and comprise lymphocytes ( $\mathrm{T}$ and $\mathrm{B}$ ) and monocytes/macrophages, principally.

It is known that $\mathrm{T}$ lymphocytes play a major role in the inflammatory response of asthma, leading to tissue remodeling and airway hyperresponsiveness; moreover, it is accepted that $B$ cells exert important functions in the adaptive immune response to this disease [182]. Exosome release from T cells has been described [183]. Several studies by Shefler et al. showed the role of EVs from these cells in the inflammatory lung response [184,185], describing their role in mast-cell activation and degranulation, releasing cytokines (IL-8 and oncostatin M) [185], linking the miR-4443 to some of these processes [184]. They demonstrate the activation of inflammatory cells through exosomes in different locations.

$\mathrm{B}$ cells were first reported to release exosomes more than twenty years ago [86]. B cell-derived exosomes carry specific molecules of antigen-presenting cells, including MHC class I and II, integrins, and costimulatory molecules (CD40, CD81, and CD86) [86,186]; these characteristics allow the exosomes to be functional units for antigen presentation, inducing $\mathrm{T}$ cell responses, modulating their proliferation and the release of IL- 5 and IL-13 cytokines. Although exosomes can conduct themselves as immunostimulatory molecules, the immunoregulatory role of these nanovesicles has also been described [187].

On the other hand, macrophages and monocytes also play several roles in asthmatic inflammation [188]. In asthma, the release of Th2 cytokines, including IL-4 and IL-13, allows macrophage polarization towards an M2 phenotype [189]. Regarding exosomes, several years ago, it was also described that macrophages could release these nanovesicles [190]. Some data could indicate that exosomes from macrophages might be implicated more in T1 immune response than in T2 response [190-192]. However, Esser et al. demonstrated that these macrophage-derived exosomes carried different enzymes implicated in LT biosynthesis, particularly $\mathrm{LTB}_{4}$, which is a potent chemoattractant agent for eosinophils and neutrophils [192]. Moreover, a recent study demonstrated that exosomes from M2 macrophages induced the differentiation of ILCs progenitors to ILC2, a potent source of immune effector cytokines in asthma [193].

Although these data demonstrate the role of exosomes from PBMCs in inflammation, more studies are necessary to elucidate the specific mechanisms of these nanovesicles on inflammatory airway diseases.

Other cell populations that could produce exosomes are polymorphonuclear cells (PMNs), which primarily comprise neutrophils, eosinophils, basophils, and mast cells. The functions of these cells in allergic and severe asthma inflammation have been widely described [145,194,195].

Neutrophils have been associated with non-T2 response and severe asthmatic phenotype [196] and are able to produce exosomes with a potential role in asthma. In 2016, Vargas et al., using an equine model of asthma, demonstrated that neutrophil exosomes contributed to airway remodeling and tissue inflammation by modulating apoptosis and proliferation of smooth muscle cells [197]. In 2016, Butin-Israeli et al. observed that EVs from neutrophils possessed MMP-9 activity, degrading proteins of the tight junctions and, consequently, breaking down epithelial unions [198]. Recently, an exhaustive study on the roles of neutrophil-derived exosomes in airway inflammation conducted by Genschmer et al. [199] described that exosomes from neutrophils that contained elastase had proteolytic activity in the extracellular matrix, contributing to inflammation, epithelial damage, and airway remodeling. Moreover, they observed that the elastase contained inside of exosomes had more powerful effects than elastase-free.

Mast cells are another granulated cell type involved in asthma pathology [200], and some authors have studied the effect of mast-cell exosomes in the modulation of allergic inflammatory responses [201]. Various groups have demonstrated different ways in which mast-cell exosomes can act in the context of asthmatic disease, finding that exosomes could 
act by interacting with cells, such as airway smooth muscle [202], exert their inflammatory functions without contact [203], or act as immunoregulatory units [204].

Basophils are a population of granulated leukocytes that comprise $0.5-1 \%$ of peripheral blood white cells and are involved in immune responses [205]. There is a lack of evidence that basophils can release exosomes [205], although some authors have described that they could release granules that resemble exosomes [206].

\section{Exosomes Released by Other Cells Implicated in Asthma Inflammation}

Aside from immune mediator cells, other cell types are implicated in asthma pathogenesis and airway remodeling, such as structural lung cells, platelets, and mesenchymal stem cells (MSCs).

Structural lung cells, including airway epithelial cells (AECs) and airway smooth muscle cells (ASMCs), play pivotal roles in asthmatic disease and inflammation $[207,208]$. T2 cytokine-stimulated exosomes presented an increase in nitric oxide synthase 2 (NOS2), and exosomes from T17-stimulated epithelial cells showed a capacity for neutrophil chemotaxis. Kulshreshtha et al. demonstrated in a murine model that stimulated IL-13 epithelial cellderived exosomes induced infiltration and proliferation of macrophages in the lungs [207]. However, most articles about exosomes from ASMCs in asthma are based on the effect of exosomes from other cell types in ASMCs [12,197,202].

On the other hand, although the roles of microparticles from platelets in airway hyperresponsiveness and bronchial remodeling have been described [209,210], unfortunately, no studies have been conducted on platelet-derived exosomes.

Finally, many studies about MSCs-derived exosomes in asthma have been performed. MSCs are pluripotent stromal cells that can reduce airway inflammation in asthma, thus increasing the proliferation of $\mathrm{T}$ regulatory cells (Treg) [211]. Recent studies showed the immunomodulatory role of MSC-derived exosomes in asthma pathogenesis [212] as well as their role in airway inflammation [213], demonstrating that exosomes from MSCs produce attenuation of airway inflammation, showing a similar effect to MSCs. This effect is produced by an increase of Treg cells and immunosuppressive cytokines, including IL-10 and TFG- $\beta$ [213]. The role of the immunosuppressive effect of MSCderived exosomes has also been studied in other inflammatory and non-inflammatory pathologies. It has been observed in eye diseases, where MSCs-derived exosomes promote regulation of Treg, providing an immunosuppressive microenvironment in the inflamed eyes [214]. Besides, immunosuppression promoting by MSCs exosomes has been observed in allergic contact dermatitis [215], diabetes [216], and in diseases with liver injury [217] by influencing Treg proliferation. Recently, Riazifar et al. demonstrated that exosomes of MSCs reduced pro-inflammatory cytokine levels and promoted Treg expansion in an experimental autoimmune encephalomyelitis model of multiple sclerosis [218]. On the other hand, different studies showed the capacity of exosomes to modulate the functions of other immune cells, such as dendritic cells [219]. Another study by Fang et al. in 2020 showed that small EVs from MSCs modulated ILC2 functions in vitro, decreasing allergic airway inflammation in mice through the delivery of miR-146a-5p [220].

The use of MSCs-derived exosomes as therapeutic tools has been widely studied and has shown promise in the field of regenerative medicine. Numerous studies have explored the therapeutic effects of exosomes from MSCs on neurological, immunological, and cardiovascular diseases [221]. Specifically, in asthma, several works have addressed this topic [222]. In 2010, Porro et al. demonstrated that exosomes from MSCs had the ability to accelerate lung tissue repair and wound healing, which could be used to alleviate asthmatic airway remodeling [223]. Other studies demonstrated that MSC-derived exosomes could mitigate airway inflammation in asthma pathology by increasing the proliferation of Treg, promoting an increase of anti-inflammatory cytokine production and immunosuppressive capacity [213]. Furthermore, exosomes from human adipose tissue-derived MSCs are able to inhibit airway hyperresponsiveness and airway inflammation in a mouse model of ovalbumin-induced asthma [224]. 
All of these studies underscore the importance of exosomes from any cell type in asthma and inflammation, as well as in the immunoregulation of this disease. As a result, exosome research is a promising field that may aid in understanding asthmatic diseases and in the search for novel therapies.

\section{Conclusions}

In the last decades, EVs have emerged as important and revolutionary elements of intercellular communication, both in physiological processes and in various pathologies. Their capacity to transport multiple elements, such as proteins, lipids, and nucleic acids, among which miRNAs are found, makes them highly relevant factors in multiple processes. All these characteristics turn these intracellular generating elements into factors of great relevance to understand, in many cases, the development of diverse diseases as well as many of their physiopathogenic mechanisms, being able to be keys to find new therapeutic approaches. The study of EVs in specific biological samples, like induced sputum or serum likewise diverse biofluids, can aid in getting knowledge about diverse pathologies, like asthma.

Author Contributions: J.A.C., B.S., J.M.R.-M., M.G.-M., and V.d.P. conceived the review and drafted the manuscript. J.A.C. and V.d.P. prepared the figures. The review was performed under the supervision of B.S. and V.d.P. All authors contributed to the article and approved the final version. All authors have read and agreed to the published version of the manuscript.

Funding: This manuscript was supported by Fondo de Investigación Sanitaria-FIS and FEDER (Fondo Europeo de Desarrollo Regional) [PI15/00803, PI18/00044, and FI16/00036], CIBERES, Merck Health Foundation funds, and RTC-2017-6501-1 (Ministerio de Ciencia, Innovación y Universidades).

Institutional Review Board Statement: Not applicable.

Informed Consent Statement: Not applicable.

Data Availability Statement: Not applicable.

Conflicts of Interest: V.d.P. has received honoraria (advisory board, speaker) and/or institutional grant/research support from Astra-Zeneca and GSK. The rest of the authors declare no conflicts of interest.

\begin{tabular}{|c|c|}
\hline Abbre & tions \\
\hline The foll & wing abbreviations are used in this \\
\hline BALF & bronchoalveolar lavage fluid \\
\hline BSMCs & bronchial smooth muscle cells \\
\hline EMT & epithelial-mesenchymal transition \\
\hline EVs & extracelular vesicles \\
\hline ICS & inhaled corticosteroid \\
\hline ILC & innate lymphoid cell \\
\hline ILVs & intraluminal vesicles \\
\hline MSCs & mesenchymal stem cells \\
\hline MVBs & multivesicular bodies \\
\hline PM & plasmatic membrane \\
\hline PMNs & polymorphonuclear cells \\
\hline Treg & regulatory $\mathrm{T}$ cells \\
\hline SAECs & small airway epithelial cells \\
\hline
\end{tabular}

\section{References}

1. Lambrecht, B.N.; Hammad, H. The immunology of asthma. Nat. Immunol. 2015, 16, 45-56. [CrossRef]

2. Mauer, Y.; Taliercio, R.M. Managing adult asthma: The 2019 GINA guidelines. Clevel. Clin. J. Med. 2020, 87, 569-575. [CrossRef]

3. Wenzel, S.E. Complex phenotypes in asthma: Current definitions. Pulm. Pharmacol. Ther. 2013, 26, 710-715. [CrossRef] [PubMed]

4. Mortaz, E.; Alipoor, S.D.; Varahram, M.; Jamaati, H.; Garssen, J.; Mumby, S.E.; Adcock, I.M. Exosomes in severe asthma: Update in their roles and potential in therapy. Biomed. Res. Int. 2018, 2018, 2862187. [CrossRef] [PubMed] 
5. Schorey, J.S.; Cheng, Y.; Singh, P.P.; Smith, V.L. Exosomes and other extracellular vesicles in host-pathogen interactions. EMBO Rep. 2015, 16, 24-43. [CrossRef]

6. Azmi, A.S.; Bao, B.; Sarkar, F.H. Exosomes in cancer development, metastasis, and drug resistance: A comprehensive review. Cancer Metastasis Rev. 2013, 32, 623-642. [CrossRef] [PubMed]

7. Cañas, J.A.; Sastre, B.; Rodrigo-Muñoz, J.M.; del Pozo, V. Exosomes: A new approach to asthma pathology. Clin. Chim. Acta 2019, 495, 139-147. [CrossRef] [PubMed]

8. Guiot, J.; Struman, I.; Louis, E.; Louis, R.; Malaise, M.; Njock, M.-S. Exosomal miRNAs in Lung Diseases: From Biologic Function to Therapeutic Targets. J. Clin. Med. 2019, 8, 1345. [CrossRef]

9. Hough, K.P.; Chanda, D.; Duncan, S.R.; Thannickal, V.J.; Deshane, J.S. Exosomes in immunoregulation of chronic lung diseases. Allergy Eur. J. Allergy Clin. Immunol. 2017, 72, 534-544. [CrossRef]

10. Van Den Berge, M.; Tasena, H. Role of microRNAs and exosomes in asthma. Curr. Opin. Pulm. Med. 2019, 25, 87-93. [CrossRef]

11. Mazzeo, C.; Cañas, J.A.; Zafra, M.P.; Rojas Marco, A.; Fernández-Nieto, M.; Sanz, V.; Mittelbrunn, M.; Izquierdo, M.; Baixaulli, F.; Sastre, J.; et al. Exosome secretion by eosinophils: A possible role in asthma pathogenesis. J. Allergy Clin. Immunol. 2015, 135, 1603-1613. [CrossRef] [PubMed]

12. Cañas, J.A.; Sastre, B.; Rodrigo-Muñoz, J.M.; Fernández-Nieto, M.; Barranco, P.; Quirce, S.; Sastre, J.; del Pozo, V. Eosinophilderived exosomes contribute to asthma remodelling by activating structural lung cells. Clin. Exp. Allergy 2018, 48, 1173-1185. [CrossRef] [PubMed]

13. Kubo, H. Extracellular Vesicles in Lung Disease. Chest 2018, 153, 210-216. [CrossRef] [PubMed]

14. Raposo, G.; Stoorvogel, W. Extracellular vesicles: Exosomes, microvesicles, and friends. J. Cell Biol. 2013, 200, 373-383. [CrossRef] [PubMed]

15. György, B.; Szabó, T.G.; Pásztói, M.; Pál, Z.; Misják, P.; Aradi, B.; László, V.; Pállinger, É.; Pap, E.; Kittel, Á.; et al. Membrane vesicles, current state-of-the-art: Emerging role of extracellular vesicles. Cell. Mol. Life Sci. 2011, 68, 2667-2688. [CrossRef] [PubMed]

16. Balaj, L.; Lessard, R.; Dai, L.; Cho, Y.J.; Pomeroy, S.L.; Breakefield, X.O.; Skog, J. Tumour microvesicles contain retrotransposon elements and amplified oncogene sequences. Nat. Commun. 2011, 2, 180. [CrossRef] [PubMed]

17. Skog, J.; Würdinger, T.; van Rijn, S.; Meijer, D.H.; Gainche, L.; Curry, W.T.; Carter, B.S.; Krichevsky, A.M.; Breakefield, X.O. Glioblastoma microvesicles transport RNA and proteins that promote tumour growth and provide diagnostic biomarkers. Nat. Cell Biol. 2008, 10, 1470-1476. [CrossRef] [PubMed]

18. Brinton, L.T.; Sloane, H.S.; Kester, M.; Kelly, K.A. Formation and role of exosomes in cancer. Cell. Mol. Life Sci. 2015, 72, 659-671. [CrossRef] [PubMed]

19. Gangoda, L.; Boukouris, S.; Liem, M.; Kalra, H.; Mathivanan, S. Extracellular vesicles including exosomes are mediators of signal transduction: Are they protective or pathogenic? Proteomics 2015, 15, 260-271. [CrossRef]

20. Bartel, S.; Deshane, J.; Wilkinson, T.; Gabrielsson, S. Extracellular Vesicles as Mediators of Cellular Cross Talk in the Lung Microenvironment. Front. Med. 2020, 7, 326. [CrossRef]

21. Keller, S.; Ridinger, J.; Rupp, A.K.; Janssen, J.W.G.; Altevogt, P. Body fluid derived exosomes as a novel template for clinical diagnostics. J. Transl. Med. 2011, 9, 86. [CrossRef] [PubMed]

22. Buzás, E.I.; Tóth, E.; Sódar, B.W.; Szabó-Taylor, K. Molecular interactions at the surface of extracellular vesicles. Semin. Immunopathol. 2018, 40, 453-464. [CrossRef] [PubMed]

23. Mulcahy, L.A.; Pink, R.C.; Carter, D.R.F. Routes and mechanisms of extracellular vesicle uptake. J. Extracell. Vesicles $2014,3,24641$. [CrossRef] [PubMed]

24. Soni, S.; Garner, J.L.; O’Dea, K.P.; Koh, M.W.; Finney, L.J.; Tirlapur, N.; Srikanthan, K.; Tenda, E.D.; Aboelhassan, A.M.A.; Singh, S.; et al. Intra-alveolar neutrophil-derived microvesicles are associated with disease severity in COPD. Am. J. Physiol. Cell. Mol. Physiol. 2020. [CrossRef] [PubMed]

25. Martinez-Bravo, M.J.; Wahlund, C.J.E.; Qazi, K.R.; Moulder, R.; Lukic, A.; Rådmark, O.; Lahesmaa, R.; Grunewald, J.; Eklund, A.; Gabrielsson, S. Pulmonary sarcoidosis is associated with exosomal vitamin D-binding protein and inflammatory molecules. $J$. Allergy Clin. Immunol. 2017, 139, 1186-1194. [CrossRef] [PubMed]

26. Meldolesi, J. Ectosomes and Exosomes-Two Extracellular Vesicles That Differ Only in Some Details. Biochem. Mol. Biol. J. 2016, 2, 1. [CrossRef]

27. Dörsam, B.; Reiners, K.S.; von Strandmann, E.P. Cancer-derived extracellular vesicles: Friend and foe of tumour immunosurveillance. Philos. Trans. R. Soc. B Biol. Sci. 2018, 373, 20160481. [CrossRef]

28. Elmore, S. Apoptosis: A Review of Programmed Cell Death. Toxicol. Pathol. 2007, 35, 495-516. [CrossRef]

29. Taylor, R.C.; Cullen, S.P.; Martin, S.J. Apoptosis: Controlled demolition at the cellular level. Nat. Rev. Mol. Cell Biol. 2008, 9, 231-241. [CrossRef]

30. Hristov, M.; Erl, W.; Linder, S.; Weber, P.C. Apoptotic bodies from endothelial cells enhance the number and initiate the differentiation of human endothelial progenitor cells in vitro. Blood 2004, 104, 2761-2766. [CrossRef]

31. Poon, I.K.H.; Lucas, C.D.; Rossi, A.G.; Ravichandran, K.S. Apoptotic cell clearance: Basic biology and therapeutic potential. Nat. Rev. Immunol. 2014, 14, 166-180. [CrossRef] [PubMed]

32. Orlando, K.A.; Stone, N.L.; Pittman, R.N. Rho kinase regulates fragmentation and phagocytosis of apoptotic cells. Exp. Cell Res. 2006, 312, 5-15. [CrossRef] [PubMed] 
33. Kerr, J.F.R.; Wyllie, A.H.; Currie, A.R. Apoptosis: A basic biological phenomenon with wide-ranging implications in tissue kinetics. Br. J. Cancer 1972, 26, 239-257. [CrossRef] [PubMed]

34. Creagh, E.M.; Conroy, H.; Martin, S.J. Caspase-activation pathways in apoptosis and immunity. Immunol. Rev. 2003, 193, 10-21. [CrossRef] [PubMed]

35. Erwig, L.P.; Henson, P.M. Clearance of apoptotic cells by phagocytes. Cell Death Differ. 2008, 15, 243-250. [CrossRef] [PubMed]

36. Takizawa, F.; Tsuji, S.; Nagasawa, S. Enhancement of macrophage phagocytosis upon iC3b deposition on apoptotic cells. FEBS Lett. 1996, 397, 269-272. [CrossRef]

37. Fadok, V.A.; Voelker, D.R.; Campbell, P.A.; Cohen, J.J.; Bratton, D.L.; Henson, P.M. Exposure of phosphatidylserine on the surface of apoptotic lymphocytes triggers specific recognition and removal by macrophages. J. Immunol. 1992, 148, $2207-2216$.

38. Akers, J.C.; Gonda, D.; Kim, R.; Carter, B.S.; Chen, C.C. Biogenesis of extracellular vesicles (EV): Exosomes, microvesicles, retrovirus-like vesicles, and apoptotic bodies. J. Neurooncol. 2013, 113, 1-11. [CrossRef]

39. Konoshenko, M.Y.; Lekchnov, E.A.; Vlassov, A.V.; Laktionov, P.P. Isolation of Extracellular Vesicles: General Methodologies and Latest Trends. Biomed Res. Int. 2018, 2018, 8545347. [CrossRef]

40. van der Pol, E.; Böing, A.N.; Harrison, P.; Sturk, A.; Nieuwland, R. Classification, functions, and clinical relevance of extracellular vesicles. Pharmacol. Rev. 2012, 64, 676-705. [CrossRef]

41. Boukouris, S.; Mathivanan, S. Exosomes in bodily fluids are a highly stable resource of disease biomarkers. Proteom. Clin. Appl. 2015, 9, 358-367. [CrossRef] [PubMed]

42. Hess, C.; Sadallah, S.; Hefti, A.; Landmann, R.; Schifferli, J. Ectosomes released by human neutrophils are specialized functional units. J. Immunol. 1999, 163, 4564-4573. [CrossRef] [PubMed]

43. Stein, J.M.; Luzio, J.P. Ectocytosis caused by sublytic autologous complement attack on human neutrophils. The sorting of endogenous plasma-membrane proteins and lipids into shed vesicles. Biochem. J. 1991, 274, 381-386. [CrossRef] [PubMed]

44. Colombo, M.; Raposo, G.; Théry, C. Biogenesis, secretion, and intercellular interactions of exosomes and other extracellular vesicles. Annu. Rev. Cell Dev. Biol. 2014, 30, 255-289. [CrossRef]

45. Muralidharan-Chari, V.; Clancy, J.W.; Sedgwick, A.; D'Souza-Schorey, C. Microvesicles: Mediators of extracellular communication during cancer progression. J. Cell Sci. 2010, 123, 1603-1611. [CrossRef]

46. D'Souza-Schorey Crislyn, C.; Clancy, J.W. Tumor-derived microvesicles: Shedding light on novel microenvironment modulators and prospective cancer biomarkers. Genes Dev. 2012, 26, 1287-1299. [CrossRef]

47. Crespin, M.; Vidal, C.; Picard, F.; Lacombe, C.; Fontenay, M. Activation of PAK1/2 during the shedding of platelet microvesicles. Blood Coagul. Fibrinolysis 2009, 20, 63-70. [CrossRef]

48. Pap, E.; Pállinger, É.; Pásztói, M.; Falus, A. Highlights of a new type of intercellular communication: Microvesicle-based information transfer. Inflamm. Res. 2009, 58, 1-8. [CrossRef]

49. Piccin, A.; Murphy, W.G.; Smith, O.P. Circulating microparticles: Pathophysiology and clinical implications. Blood Rev. 2007, 21, 157-171. [CrossRef]

50. Leventis, P.A.; Grinstein, S. The distribution and function of phosphatidylserine in cellular membranes. Annu. Rev. Biophys. 2010, 39, 407-427. [CrossRef]

51. Hugel, B.; Martínez, M.C.; Kunzelmann, C.; Freyssinet, J.M. Membrane microparticles: Two sides of the coin. Physiology 2005, 20, 22-27. [CrossRef] [PubMed]

52. McConnell, R.E.; Higginbotham, J.N.; Shifrin, D.A.; Tabb, D.L.; Coffey, R.J.; Tyska, M.J. The enterocyte microvillus is a vesiclegenerating organelle. J. Cell Biol. 2009, 185, 1285-1298. [CrossRef] [PubMed]

53. Antonyak, M.A.; Wilson, K.F.; Cerione, R.A. R(h)oads to microvesicles. Small GTPases 2012, 3, 219-224. [CrossRef] [PubMed]

54. Wang, T.; Gilkes, D.M.; Takano, N.; Xiang, L.; Luo, W.; Bishop, C.J.; Chaturvedi, P.; Green, J.J.; Semenza, G.L. Hypoxia-inducible factors and RAB22A mediate formation of microvesicles that stimulate breast cancer invasion and metastasis. Proc. Natl. Acad. Sci. USA 2014, 111, E3234-E3242. [CrossRef]

55. Muralidharan-Chari, V.; Clancy, J.; Plou, C.; Romao, M.; Chavrier, P.; Raposo, G.; D'Souza-Schorey, C. ARF6-Regulated Shedding of Tumor Cell-Derived Plasma Membrane Microvesicles. Curr. Biol. 2009, 19, 1875-1885. [CrossRef] [PubMed]

56. Schlienger, S.; Campbell, S.; Claing, A. ARF1 regulates the Rho/MLC pathway to control EGF-dependent breast cancer cell invasion. Mol. Biol. Cell 2014, 25, 17-29. [CrossRef]

57. Cocucci, E.; Racchetti, G.; Meldolesi, J. Shedding microvesicles: Artefacts no more. Trends Cell Biol. 2009, 19, 43-51. [CrossRef]

58. Latham, S.L.; Tiberti, N.; Gokoolparsadh, N.; Holdaway, K.; Couraud, P.O.; Grau, G.E.R.; Combes, V. Immuno-analysis of microparticles: Probing at the limits of detection. Sci. Rep. 2015, 5, 16314. [CrossRef]

59. Weerheim, A.M.; Kolb, A.M.; Sturk, A.; Nieuwland, R. Phospholipid composition of cell-derived microparticles determined by one-dimensional high-performance thin-layer chromatography. Anal. Biochem. 2002, 302, 191-198. [CrossRef]

60. De Lizarrondo, S.M.; Roncal, C.; Calvayrac, O.; Rodríguez, C.; Varo, N.; Purroy, A.; Lorente, L.; Rodríguez, J.A.; Doeuvre, L.; Hervás-Stubbs, S.; et al. Synergistic effect of thrombin and CD40 ligand on endothelial matrix metalloproteinase-10 expression and microparticle generation in vitro and in vivo. Arterioscler. Thromb. Vasc. Biol. 2012, 32, 1477-1487. [CrossRef]

61. Holliday, L.S.; de Faria, L.P.; Rody, W.J. Actin and actin-associated proteins in extracellular vesicles shed by osteoclasts. Int. J. Mol. Sci. 2020, 21, 158. [CrossRef] [PubMed] 
62. Mezouar, S.; Darbousset, R.; Dignat-George, F.; Panicot-Dubois, L.; Dubois, C. Inhibition of platelet activation prevents the P-selectin and integrin-dependent accumulation of cancer cell microparticles and reduces tumor growth and metastasis in vivo. Int. J. Cancer 2015, 136, 462-475. [CrossRef] [PubMed]

63. Al-Nedawi, K.; Meehan, B.; Micallef, J.; Lhotak, V.; May, L.; Guha, A.; Rak, J. Intercellular transfer of the oncogenic receptor EGFRvIII by microvesicles derived from tumour cells. Nat. Cell Biol. 2008, 10, 619-624. [CrossRef] [PubMed]

64. Martinez, M.C.; Tual-Chalot, S.; Leonetti, D.; Andriantsitohaina, R. Microparticles: Targets and tools in cardiovascular disease. Trends Pharmacol. Sci. 2011, 32, 659-665. [CrossRef] [PubMed]

65. Johnstone, R.M.; Adam, M.; Hammond, J.R.; Orr, L.; Turbide, C. Vesicle formation during reticulocyte maturation. Association of plasma membrane activities with released vesicles (exosomes). J. Biol. Chem. 1987, 262, 9412-9420. [CrossRef] [PubMed]

66. Pan, B.T.; Teng, K.; Wu, C.; Adam, M.; Johnstone, R.M. Electron microscopic evidence for externalization of the transferrin receptor in vesicular form in sheep reticulocytes. J. Cell Biol. 1985, 101, 942-948. [CrossRef]

67. Cocucci, E.; Meldolesi, J. Ectosomes and exosomes: Shedding the confusion between extracellular vesicles. Trends Cell Biol. 2015, 25, 364-372. [CrossRef]

68. Grant, B.D.; Donaldson, J.G. Pathways and mechanisms of endocytic recycling. Nat. Rev. Mol. Cell Biol. 2009, 10, 597-608. [CrossRef]

69. Colombo, M.; Moita, C.; Van Niel, G.; Kowal, J.; Vigneron, J.; Benaroch, P.; Manel, N.; Moita, L.F.; Théry, C.; Raposo, G. Analysis of ESCRT functions in exosome biogenesis, composition and secretion highlights the heterogeneity of extracellular vesicles. J. Cell Sci. 2013, 126, 5553-5565. [CrossRef]

70. Pols, M.S.; Klumperman, J. Trafficking and function of the tetraspanin CD63. Exp. Cell Res. 2009, 315, 1584-1592. [CrossRef]

71. Henne, W.M.; Buchkovich, N.J.; Emr, S.D. The ESCRT Pathway. Dev. Cell 2011, 21, 77-91. [CrossRef] [PubMed]

72. Marsh, M.; Van Meer, G. Cell biology: No ESCRTs for exosomes. Science 2008, 319, 1191-1192. [CrossRef] [PubMed]

73. Ghossoub, R.; Lembo, F.; Rubio, A.; Gaillard, C.B.; Bouchet, J.; Vitale, N.; Slavík, J.; Machala, M.; Zimmermann, P. Syntenin-ALIX exosome biogenesis and budding into multivesicular bodies are controlled by ARF6 and PLD2. Nat. Commun. 2014, 5, 3477. [CrossRef] [PubMed]

74. Laulagnier, K.; Motta, C.; Hamdi, S.; Roy, S.; Fauvelle, F.; Pageaux, J.F.; Kobayashi, T.; Salles, J.P.; Perret, B.; Bonnerot, C.; et al. Mast cell- and dendritic cell-derived display a specific lipid composition and an unusual membrane organization. Biochem. J. 2004, 380, 161-171. [CrossRef] [PubMed]

75. Trajkovic, K.; Hsu, C.; Chiantia, S.; Rajendran, L.; Wenzel, D.; Wieland, F.; Schwille, P.; Brügger, B.; Simons, M. Ceramide triggers budding of exosome vesicles into multivesicular endosomes. Science 2008, 319, 1244-1247. [CrossRef]

76. Fader, C.M.; Sánchez, D.G.; Mestre, M.B.; Colombo, M.I. TI-VAMP/VAMP7 and VAMP3/cellubrevin: Two v-SNARE proteins involved in specific steps of the autophagy/multivesicular body pathways. Biochim. Biophys. Acta Mol. Cell Res. 2009, 1793, 1901-1916. [CrossRef]

77. Stenmark, H. Rab GTPases as coordinators of vesicle traffic. Nat. Rev. Mol. Cell Biol. 2009, 10, 513-525. [CrossRef]

78. Wubbolts, R.; Leckie, R.S.; Veenhuizen, P.T.M.; Schwarzmann, G.; Möbius, W.; Hoernschemeyer, J.; Slot, J.W.; Geuze, H.J.; Stoorvogel, W. Proteomic and biochemical analyses of human B cell-derived exosomes: Potential implications for their function and multivesicular body formation. J. Biol. Chem. 2003, 278, 10963-10972. [CrossRef]

79. Frydrychowicz, M.; Kolecka-Bednarczyk, A.; Madejczyk, M.; Yasar, S.; Dworacki, G. Exosomes-structure, biogenesis and biological role in non-small-cell lung cancer. Scand. J. Immunol. 2015, 81, 2-10. [CrossRef]

80. Mathivanan, S.; Ji, H.; Simpson, R.J. Exosomes: Extracellular organelles important in intercellular communication. J. Proteom. 2010, 73, 1907-1920. [CrossRef]

81. Conde-Vancells, J.; Rodriguez-Suarez, E.; Embade, N.; Gil, D.; Matthiesen, R.; Valle, M.; Elortza, F.; Lu, S.C.; Mato, J.M.; FalconPerez, J.M. Characterization and comprehensive proteome profiling of exosomes secreted by hepatocytes. J. Proteome Res. 2008, 7, 5157-5166. [CrossRef] [PubMed]

82. Bobrie, A.; Colombo, M.; Raposo, G.; Théry, C. Exosome Secretion: Molecular Mechanisms and Roles in Immune Responses. Traffic 2011, 12, 1659-1668. [CrossRef] [PubMed]

83. Torralba, D.; Baixauli, F.; Villarroya-Beltri, C.; Fernández-Delgado, I.; Latorre-Pellicer, A.; Acín-Pérez, R.; Martín-Cófreces, N.B.; Jaso-Tamame, Á.L.; Iborra, S.; Jorge, I.; et al. Priming of dendritic cells by DNA-containing extracellular vesicles from activated T cells through antigen-driven contacts. Nat. Commun. 2018, 9, 2658. [CrossRef]

84. Serrano-Pertierra, E.; Oliveira-Rodríguez, M.; Rivas, M.; Oliva, P.; Villafani, J.; Navarro, A.; Blanco-López, M.C.; CernudaMorollón, E. Characterization of plasma-derived extracellular vesicles isolated by different methods: A comparison study. Bioengineering 2019, 6, 8. [CrossRef] [PubMed]

85. Sunkara, V.; Woo, H.K.; Cho, Y.K. Emerging techniques in the isolation and characterization of extracellular vesicles and their roles in cancer diagnostics and prognostics. Analyst 2016, 141, 371-381. [CrossRef]

86. Raposo, G.; Nijman, H.W.; Stoorvogel, W.; Leijendekker, R.; Harding, C.V.; Melief, C.J.M.; Geuze, H.J. B lymphocytes secrete antigen-presenting vesicles. J. Exp. Med. 1996, 183, 1161-1172. [CrossRef]

87. Lee, H.; Zhang, D.; Zhu, Z.; Dela Cruz, C.S.; Jin, Y. Epithelial cell-derived microvesicles activate macrophages and promote inflammation via microvesicle-containing microRNAs. Sci. Rep. 2016, 6, 35250. [CrossRef]

88. Cvjetkovic, A.; Lötvall, J.; Lässer, C. The influence of rotor type and centrifugation time on the yield and purity of extracellular vesicles. J. Extracell. Vesicles 2014, 3, 23111. [CrossRef] 
89. Théry, C.; Ostrowski, M.; Segura, E. Membrane vesicles as conveyors of immune responses. Nat. Rev. Immunol. 2009,9 , 581-593. [CrossRef]

90. Yamamoto, K.R.; Alberts, B.M.; Benzinger, R.; Lawhorne, L.; Treiber, G. Rapid bacteriophage sedimentation in the presence of polyethylene glycol and its application to large-scale virus purification. Virology 1970, 40, 734-744. [CrossRef]

91. Gámez-Valero, A.; Monguió-Tortajada, M.; Carreras-Planella, L.; Franquesa, M.; Beyer, K.; Borràs, F.E. Size-Exclusion Chromatography-based isolation minimally alters Extracellular Vesicles' characteristics compared to precipitating agents. Sci. Rep. 2016, 6, 33641. [CrossRef] [PubMed]

92. Merchant, M.L.; Powell, D.W.; Wilkey, D.W.; Cummins, T.D.; Deegens, J.K.; Rood, I.M.; McAfee, K.J.; Fleischer, C.; Klein, E.; Klein, J.B. Microfiltration isolation of human urinary exosomes for characterization by MS. Proteom. Clin. Appl. 2010, 4, 84-96. [CrossRef] [PubMed]

93. Lobb, R.J.; Becker, M.; Wen, S.W.; Wong, C.S.F.; Wiegmans, A.P.; Leimgruber, A.; Möller, A. Optimized exosome isolation protocol for cell culture supernatant and human plasma. J. Extracell. Vesicles 2015, 4, 27031. [CrossRef] [PubMed]

94. Crowell, A.M.J.; Wall, M.J.; Doucette, A.A. Maximizing recovery of water-soluble proteins through acetone precipitation. Anal. Chim. Acta 2013, 796, 48-54. [CrossRef]

95. Brownlee, Z.; Lynn, K.D.; Thorpe, P.E.; Schroit, A.J. A novel "salting-out" procedure for the isolation of tumor-derived exosomes. J. Immunol. Methods 2014, 407, 120-126. [CrossRef] [PubMed]

96. Deregibus, M.C.; Figliolini, F.; D'Antico, S.; Manzini, P.M.; Pasquino, C.; De Lena, M.; Tetta, C.; Brizzi, M.F.; Camussi, G. Charge-based precipitation of extracellular vesicles. Int. J. Mol. Med. 2016, 38, 1359-1366. [CrossRef]

97. Rider, M.A.; Hurwitz, S.N.; Meckes, D.G. ExtraPEG: A polyethylene glycol-based method for enrichment of extracellular vesicles. Sci. Rep. 2016, 6, 23978. [CrossRef]

98. Heath, N.; Grant, L.; De Oliveira, T.M.; Rowlinson, R.; Osteikoetxea, X.; Dekker, N.; Overman, R. Rapid isolation and enrichment of extracellular vesicle preparations using anion exchange chromatography. Sci. Rep. 2018, 8, 5730. [CrossRef]

99. Kowal, J.; Arras, G.; Colombo, M.; Jouve, M.; Morath, J.P.; Primdal-Bengtson, B.; Dingli, F.; Loew, D.; Tkach, M.; Théry, C. Proteomic comparison defines novel markers to characterize heterogeneous populations of extracellular vesicle subtypes. Proc. Natl. Acad. Sci. USA 2016, 113, E968-E977. [CrossRef]

100. Carnino, J.M.; Lee, H.; Jin, Y. Isolation and characterization of extracellular vesicles from Broncho-Alveolar lavage fluid: A review and comparison of different methods. Respir. Res. 2019, 20, 240. [CrossRef]

101. Lee, H.; Groot, M.; Pinilla-Vera, M.; Fredenburgh, L.E.; Jin, Y. Identification of miRNA-rich vesicles in bronchoalveolar lavage fluid: Insights into the function and heterogeneity of extracellular vesicles. J. Control. Release 2019, 294, 43-52. [CrossRef] [PubMed]

102. Prado, N.; Cañamero, M.; Villalba, M.; Rodríguez, R.; Batanero, E. Bystander suppression to unrelated allergen sensitization through intranasal administration of tolerogenic exosomes in mouse. Mol. Immunol. 2010, 47, 2148-2151. [CrossRef] [PubMed]

103. Prado, N.; Marazuela, E.G.; Segura, E.; Fernández-García, H.; Villalba, M.; Théry, C.; Rodríguez, R.; Batanero, E. Exosomes from Bronchoalveolar Fluid of Tolerized Mice Prevent Allergic Reaction. J. Immunol. 2008, 181, 1519-1525. [CrossRef] [PubMed]

104. Shin, T.S.; Kim, J.H.; Kim, Y.S.; Jeon, S.G.; Zhu, Z.; Gho, Y.S.; Kim, Y.K. Extracellular vesicles are key intercellular mediators in the development of immune dysfunction to allergens in the airways. Allergy Eur. J. Allergy Clin. Immunol. 2010, 65, 1256-1265. [CrossRef] [PubMed]

105. Torregrosa Paredes, P.; Esser, J.; Admyre, C.; Nord, M.; Rahman, Q.K.; Lukic, A.; Rådmark, O.; Grönneberg, R.; Grunewald, J.; Eklund, A.; et al. Bronchoalveolar lavage fluid exosomes contribute to cytokine and leukotriene production in allergic asthma. Allergy Eur. J. Allergy Clin. Immunol. 2012, 67, 911-919. [CrossRef]

106. Hough, K.P.; Wilson, L.S.; Trevor, J.L.; Strenkowski, J.G.; Maina, N.; Kim, Y.I.; Spell, M.L.; Wang, Y.; Chanda, D.; Dager, J.R.; et al. Unique Lipid Signatures of Extracellular Vesicles from the Airways of Asthmatics. Sci. Rep. 2018, 8, 10340. [CrossRef]

107. Mohan, A.; Agarwal, S.; Clauss, M.; Britt, N.S.; Dhillon, N.K. Extracellular vesicles: Novel communicators in lung diseases. Respir. Res. 2020, 21, 175. [CrossRef]

108. Rollet-Cohen, V.; Bourderioux, M.; Lipecka, J.; Chhuon, C.; Jung, V.A.; Mesbahi, M.; Nguyen-Khoa, T.; Guérin-Pfyffer, S.; Schmitt, A.; Edelman, A.; et al. Comparative proteomics of respiratory exosomes in cystic fibrosis, primary ciliary dyskinesia and asthma. J. Proteom. 2018, 185, 1-7. [CrossRef]

109. Wu, S.Q.; Wang, G.L.; Li, L.Y.; Ji, J. Effects of microRNA-21 on the interleukin 12/signal transducer and activator of transcription 4 signaling pathway in asthmatic mice. Cent. Eur. J. Immunol. 2014, 39, 40-45. [CrossRef]

110. Li, P.; Wang, J.; Guo, F.; Zheng, B.; Zhang, X. A novel inhibitory role of microRNA-224 in particulate matter 2.5-induced asthmatic mice by inhibiting TLR2. J. Cell. Mol. Med. 2020, 24, 3040-3052. [CrossRef]

111. Gon, Y.; Maruoka, S.; Inoue, T.; Kuroda, K.; Yamagishi, K.; Kozu, Y.; Shikano, S.; Soda, K.; Lötvall, J.; Hashimoto, S. Selective release of miRNAs via extracellular vesicles is associated with house-dust mite allergen-induced airway inflammation. Clin. Exp. Allergy 2017, 47, 1586-1598. [CrossRef] [PubMed]

112. Levänen, B.; Bhakta, N.R.; Torregrosa Paredes, P.; Barbeau, R.; Hiltbrunner, S.; Pollack, J.L.; Sköld, C.M.; Svartengren, M.; Grunewald, J.; Gabrielsson, S.; et al. Altered microRNA profiles in bronchoalveolar lavage fluid exosomes in asthmatic patients. J. Allergy Clin. Immunol. 2013, 131, 894-903. [CrossRef] [PubMed] 
113. Francisco-Garcia, A.S.; Garrido-Martín, E.M.; Rupani, H.; Lau, L.C.K.; Martinez-Nunez, R.T.; Howarth, P.H.; Sanchez-Elsner, T. Small RNA species and micro RNA profiles are altered in severe asthma nanovesicles from broncho alveolar lavage and associate with impaired lung function and inflammation. Non-coding RNA 2019, 5, 51. [CrossRef] [PubMed]

114. Maes, T.; Cobos, F.A.; Schleich, F.; Sorbello, V.; Henket, M.; De Preter, K.; Bracke, K.R.; Conickx, G.; Mesnil, C.; Vandesompele, J.; et al. Asthma inflammatory phenotypes show differential microRNA expression in sputum. J. Allergy Clin. Immunol. 2016, 137, 1433-1446. [CrossRef] [PubMed]

115. Zhang, K.; Liang, Y.; Feng, Y.; Wu, W.; Zhang, H.; He, J.; Hu, Q.; Zhao, J.; Xu, Y.; Liu, Z.; et al. Decreased epithelial and sputum miR-221-3p associates with airway eosinophilic inflammation and CXCL17 expression in asthma. Am. J. Physiol. Lung Cell. Mol. Physiol. 2018, 315, L253-L264. [CrossRef] [PubMed]

116. Elbehidy, R.M.; Youssef, D.M.; El-Shal, A.S.; Shalaby, S.M.; Sherbiny, H.S.; Sherief, L.M.; Akeel, N.E. MicroRNA-21 as a novel biomarker in diagnosis and response to therapy in asthmatic children. Mol. Immunol. 2016, 71, 107-114. [CrossRef] [PubMed]

117. Karam, R.A.; Abd Elrahman, D.M. Differential expression of miR-155 and Let-7a in the plasma of childhood asthma: Potential biomarkers for diagnosis and severity. Clin. Biochem. 2019, 68, 30-36. [CrossRef]

118. Yu, B.; Yao, L.; Liu, C.; Tang, L.; Xing, T. Upregulation of microRNA-16 alters the response to inhaled $\beta$-agonists in patients with asthma though modulating expression of ADRB2. Mol. Med. Rep. 2019, 49, 4027-4034. [CrossRef]

119. Huang, Y.; Zhang, S.; Fang, X.; Qin, L.; Fan, Y.; Ding, D.; Liu, X.; Xie, M. Plasma miR-199a-5p is increased in neutrophilic phenotype asthma patients and negatively correlated with pulmonary function. PLoS ONE 2018, 13, e0193502. [CrossRef]

120. Huo, X.; Zhang, K.; Yi, L.; Mo, Y.; Liang, Y.; Zhao, J.; Zhang, Z.; Xu, Y.; Zhen, G. Decreased epithelial and plasma miR-181b-5p expression associates with airway eosinophilic inflammation in asthma. Clin. Exp. Allergy 2016, 46, 1281-1290. [CrossRef]

121. Kho, A.T.; McGeachie, M.J.; Moore, K.G.; Sylvia, J.M.; Weiss, S.T.; Tantisira, K.G. Circulating microRNAs and prediction of asthma exacerbation in childhood asthma. Respir. Res. 2018, 19, 128. [CrossRef] [PubMed]

122. Shi, Z.G.; Sun, Y.; Wang, K.S.; Jia, J.D.; Yang, J.; Li, Y.N. Effects of mir-26a/mir-146a/miR-31 on airway inflammation of asthma mice and asthma children. Eur. Rev. Med. Pharmacol. Sci. 2019, 23, 5432-5440. [CrossRef] [PubMed]

123. Zhang, H.H.; Li, C.X.; Tang, L.F. The Differential Expression Profiles of miRNA-let 7a, 7b, and 7c in Bronchoalveolar Lavage Fluid From Infants With Asthma and Airway Foreign Bodies. J. Evid. Based Integr. Med. 2019, 24, 2515690X18821906. [CrossRef] [PubMed]

124. Sánchez-Vidaurre, S.; Eldh, M.; Larssen, P.; Daham, K.; Martinez-Bravo, M.J.; Dahlén, S.E.; Dahlén, B.; van Hage, M.; Gabrielsson, S. RNA-containing exosomes in induced sputum of asthmatic patients. J. Allergy Clin. Immunol. 2017, 140, 1459-1461.e2. [CrossRef]

125. Liu, Z.; Chen, X.; Wu, Q.; Song, J.; Wang, L.; Li, G. MiR-125b inhibits goblet cell differentiation in allergic airway inflammation by targeting SPDEF. Eur. J. Pharmacol. 2016, 782, 14-20. [CrossRef]

126. Lacedonia, D.; Palladino, G.P.; Foschino-Barbaro, M.P.; Scioscia, G.; Carpagnano, G.E. Expression profiling of miRNA-145 and miRNA-338 in serum and sputum of patients with COPD, asthma, and asthma-COPD overlap syndrome phenotype. Int. $J$. COPD 2017, 12, 1811-1817. [CrossRef]

127. Malmhäll, C.; Johansson, K.; Winkler, C.; Alawieh, S.; Ekerljung, L.; Rådinger, M. Altered miR-155 Expression in Allergic Asthmatic Airways. Scand. J. Immunol. 2017, 85, 300-307. [CrossRef]

128. Gomez, J.L.; Chen, A.; Diaz, M.P.; Zirn, N.; Gupta, A.; Britto, C.; Sauler, M.; Yan, X.; Stewart, E.; Santerian, K.; et al. A Network of Sputum MicroRNAs Is Associated with Neutrophilic Airway Inflammation in Asthma. Am. J. Respir. Crit. Care Med. 2020, 202, 51-64. [CrossRef]

129. Sastre, B.; Cañas, J.A.; Rodrigo-Muñoz, J.M.; del Pozo, V. Novel modulators of asthma and allergy: Exosomes and microRNAs. Front. Immunol. 2017, 8, 826. [CrossRef]

130. ElKashef, S.M.M.A.E.; Ahmad, S.E.A.; Soliman, Y.M.A.; Mostafa, M.S. Role of microRNA-21 and microRNA-155 as biomarkers for bronchial asthma. Innate Immun. 2020. [CrossRef]

131. Panganiban, R.P.L.; Pinkerton, M.H.; Maru, S.Y.; Jefferson, S.J.; Roff, A.N.; Ishmael, F.T. Differential microRNA epression in asthma and the role of miR-1248 in regulation of IL-5. Am. J. Clin. Exp. Immunol. 2012, 1, 154-165. [PubMed]

132. Liu, Q.; Wang, W.; Jing, W. Indoor air pollution aggravates asthma in Chinese children and induces the changes in serum level of miR-155. Int. J. Environ. Health Res. 2019, 29, 22-30. [CrossRef] [PubMed]

133. Li, J.; Panganiban, R.; Kho, A.T.; McGeachie, M.J.; Farnam, L.; Chase, R.P.; Weiss, S.T.; Lu, Q.; Tantisira, K.G. Circulating MicroRNAs and Treatment Response in Childhood Asthma. Am. J. Respir. Crit. Care Med. 2020, 202, 65-72. [CrossRef] [PubMed]

134. Weidner, J.; Ekerljung, L.; Malmhäll, C.; Miron, N.; Rådinger, M. Circulating microRNAs correlate to clinical parameters in individuals with allergic and non-allergic asthma. Respir. Res. 2020, 21, 107. [CrossRef] [PubMed]

135. Fan, Q.; Jian, Y. MiR-203a-3p regulates TGF- $\beta 1$-induced epithelial-mesenchymal transition (EMT) in asthma by regulating Smad3 pathway through SIX1. Biosci. Rep. 2020, 40, BSR20192645. [CrossRef] [PubMed]

136. Yang, Z.C.; Qu, Z.H.; Yi, M.J.; Shan, Y.C.; Ran, N.; Xu, L.; Liu, X.J. MiR-448-5p inhibits TGF- $\beta 1$-induced epithelial-mesenchymal transition and pulmonary fibrosis by targeting Six1 in asthma. J. Cell. Physiol. 2019, 234, 8804-8814. [CrossRef]

137. Du, J.; Wu, H.; Wu, Y. MiR-98-5p may be a biomarker for screening bronchial asthma in children by targeting IL-13. Clin. Lab. 2019, 65, 387-393. [CrossRef] 
138. Rodrigo-Muñoz, J.M.; Cañas, J.A.; Sastre, B.; Rego, N.; Greif, G.; Rial, M.; Mínguez, P.; Mahíllo-Fernández, I.; Fernández-Nieto, M.; Mora, I.; et al. Asthma diagnosis using integrated analysis of eosinophil microRNAs. Allergy Eur. J. Allergy Clin. Immunol. 2019, 74, 507-517. [CrossRef]

139. Lee, J.H.; Choi, J.P.; Yang, J.; Won, H.K.; Park, C.S.; Song, W.J.; Kwon, H.S.; Kim, T.B.; Kim, Y.K.; Park, H.S.; et al. Metagenome analysis using serum extracellular vesicles identified distinct microbiota in asthmatics. Sci. Rep. 2020, 10, 15125. [CrossRef]

140. Kim, Y.-Y.; Joh, J.S.; Lee, J.Y. Importance of microbial extracellular vesicle in the pathogenesis of asthma and chronic obstructive pulmonary disease and its diagnostic potential. Asia Pac. Allergy 2020, 10, 25. [CrossRef]

141. Eitan, E.; Green, J.; Bodogai, M.; Mode, N.A.; Bæk, R.; Jørgensen, M.M.; Freeman, D.W.; Witwer, K.W.; Zonderman, A.B.; Biragyn, A.; et al. Age-Related Changes in Plasma Extracellular Vesicle Characteristics and Internalization by Leukocytes. Sci. Rep. 2017, 7, 1342. [CrossRef] [PubMed]

142. Sastre, B.; Rodrigo-Muñoz, J.M.; Garcia-Sanchez, D.A.; Cañas, J.A.; Del Pozo, V. Eosinophils: Old players in a new game. J. Investig. Allergol. Clin. Immunol. 2018, 28, 289-304. [CrossRef] [PubMed]

143. Eng, S.S.; Defelice, M.L. The role and immunobiology of eosinophils in the respiratory system: A comprehensive review. Clin. Rev. Allergy Immunol. 2016, 50, 140-158. [CrossRef] [PubMed]

144. Fukuda, T.; Fukushima, Y.; Numao, T.; Ando, N.; Arima, M.; Nakajima, H.; Sagara, H.; Adachi, T.; Motojima, S.; Makino, S. Role of Interleukin-4 and Vascular Cell Adhesion Molecule-1 in Selective Eosinophil Migration into the Airways in Allergic Asthma. Am. J. Respir. Cell Mol. Biol. 1996, 14, 84-94. [CrossRef] [PubMed]

145. McBrien, C.N.; Menzies-Gow, A. The biology of eosinophils and their role in asthma. Front. Med. 2017, 4, 93. [CrossRef]

146. Venge, J.; Lampinen, M.; Håkansson, L.; Rak, S.; Venge, P. Identification of IL-5 and RANTES as the major eosinophil chemoattractants in the asthmatic lung. J. Allergy Clin. Immunol. 1996, 97, 1110-1115. [CrossRef]

147. Lloyd, C.M.; Hessel, E.M. Functions of T cells in asthma: More than just TH2 cells. Nat. Rev. Immunol. 2010, 10, 838-848. [CrossRef]

148. Zhu, J. T helper 2 (Th2) cell differentiation, type 2 innate lymphoid cell (ILC2) development and regulation of interleukin-4 (IL-4) and IL-13 production. Cytokine 2015, 75, 14-24. [CrossRef]

149. Mitchell, P.D.; O’Byrne, P.M. Epithelial-Derived Cytokines in Asthma. Chest 2017, 151, 1338-1344. [CrossRef]

150. Chen, R.; Smith, S.G.; Salter, B.; El-Gammal, A.; Oliveria, J.P.; Obminski, C.; Watson, R.; O’Byrne, P.M.; Gauvreau, G.M.; Sehmi, R. Allergen-induced increases in sputum levels of group 2 innate lymphoid cells in subjects with asthma. Am. J. Respir. Crit. Care Med. 2017, 196, 700-712. [CrossRef]

151. Melo, R.C.N.; Dvorak, A.M.; Weller, P.F. Contributions of electron microscopy to understand secretion of immune mediators by human eosinophils. Microsc. Microanal. 2010, 16, 653-660. [CrossRef] [PubMed]

152. Neves, J.S.; Weller, P.F. Functional extracellular eosinophil granules: Novel implications in eosinophil immunobiology. Curr. Opin. Immunol. 2009, 21, 694-699. [CrossRef] [PubMed]

153. Neves, J.S.; Perez, S.A.C.; Spencer, L.A.; Melo, R.C.N.; Reynolds, L.; Ghiran, I.; Mahmudi-Azer, S.; Odemuyiwa, S.O.; Dvorak, A.M.; Moqbel, R.; et al. Eosinophil granules function extracellularly as receptor-mediated secretory organelles. Proc. Natl. Acad. Sci. USA 2008, 105, 18478-18483. [CrossRef] [PubMed]

154. Melo, R.C.N.; Weller, P.F. Piecemeal degranulation in human eosinophils: A distinct secretion mechanism underlying inflammatory responses. Histol. Histopathol. 2010, 25, 1341-1354. [CrossRef] [PubMed]

155. Melo, R.C.N.; Perez, S.A.C.; Spencer, L.A.; Dvorak, A.M.; Weller, P.F. Intragranular vesiculotubular compartments are involved in piecemeal degranulation by activated human eosinophils. Traffic 2005, 6, 866-879. [CrossRef]

156. Melo, R.C.N.; Spencer, L.A.; Perez, S.A.C.; Neves, J.S.; Bafford, S.P.; Morgan, E.S.; Dvorak, A.M.; Weller, P.F. Vesicle-mediated secretion of human eosinophil granule-derived major basic protein. Lab. Investig. 2009, 89, 769-781. [CrossRef] [PubMed]

157. Spencer, L.A.; Bonjour, K.; Melo, R.C.N.; Weller, P.F. Eosinophil secretion of granule-derived cytokines. Front. Immunol. 2014, 5, 496. [CrossRef]

158. Melo, R.C.N.; Spencer, L.A.; Dvorak, A.M.; Weller, P.F. Mechanisms of eosinophil secretion: Large vesiculotubular carriers mediate transport and release of granule-derived cytokines and other proteins. J. Leukoc. Biol. 2008, 83, 229-236. [CrossRef]

159. Gleich, G.J.; Flavahan, N.A.; Fujisawa, T.; Vanhoutte, P.M. The eosinophil as a mediator of damage to respiratory epithelium: A model for bronchial hyperreactivity. J. Allergy Clin. Immunol. 1988, 81, 776-781. [CrossRef]

160. Venge, P.; Dahl, R.; Fredens, K.; Peterson, C.G.B. Epithelial injury by human eosinophils. Am. Rev. Respir. Dis. 1988, 138, $154-157$. [CrossRef]

161. Schwingshackl, A.; Duszyk, M.; Brown, N.; Moqbel, R. Human eosinophils release matrix metalloproteinase-9 on stimulation with TNF- $\alpha$. J. Allergy Clin. Immunol. 1999, 104, 983-990. [CrossRef]

162. Luna-Gomes, T.; Bozza, P.T.; Bandeira-Melo, C. Eosinophil recruitment and activation: The role of lipid mediators. Front. Pharmacol. 2013, 4, 27. [CrossRef] [PubMed]

163. Sanders, S.P.; Zweier, J.L.; Harrison, S.J.; Trush, M.A.; Rembish, S.J.; Liu, M.C. Spontaneous oxygen radical production at sites of antigen challenge in allergic subjects. Am. J. Respir. Crit. Care Med. 1995, 151, 1725-1733. [CrossRef] [PubMed]

164. Spencer, L.A.; Szela, C.T.; Perez, S.A.C.; Kirchhoffer, C.L.; Neves, J.S.; Radke, A.L.; Weller, P.F. Human eosinophils constitutively express multiple Th1, Th2, and immunoregulatory cytokines that are secreted rapidly and differentially. J. Leukoc. Biol. 2008, 85, 117-123. [CrossRef] 
165. Melo, R.C.N.; Spencer, L.A.; Perez, S.A.C.; Ghiran, I.; Dvorak, A.M.; Weller, P.F. Human eosinophils secrete preformed, granulestored interleukin-4 through distinct vesicular compartments. Traffic 2005, 6, 1047-1057. [CrossRef]

166. Bandeira-Melo, C.; Sugiyama, K.; Woods, L.J.; Weller, P.F. Cutting Edge: Eotaxin Elicits Rapid Vesicular Transport-Mediated Release of Preformed IL-4 from Human Eosinophils. J. Immunol. 2001, 166, 4813-4817. [CrossRef]

167. Bandeira-Melo, C.; Weller, P.F. Mechanisms of eosinophil cytokine release. Mem. Inst. Oswaldo Cruz 2005, 100, 73-81. [CrossRef]

168. Carmo, L.A.S.; Bonjour, K.; Spencer, L.A.; Weller, P.F.; Melo, R.C.N. Single-cell analyses of human eosinophils at high resolution to understand compartmentalization and vesicular trafficking of interferon-gamma. Front. Immunol. 2018, 9, 1542. [CrossRef]

169. Mukherjee, M.; Lacy, P.; Ueki, S. Eosinophil extracellular traps and inflammatory pathologies-untangling the web! Front. Immunol. 2018, 9, 2763. [CrossRef]

170. Ueki, S.; Tokunaga, T.; Melo, R.C.N.; Saito, H.; Honda, K.; Fukuchi, M.; Konno, Y.; Takeda, M.; Yamamoto, Y.; Hirokawa, M.; et al. Charcot-Leyden crystal formation is closely associated with eosinophil extracellular trap cell death. Blood 2018, 132, $2183-2187$. [CrossRef]

171. Ueki, S.; Melo, R.C.N.; Ghiran, I.; Spencer, L.A.; Dvorak, A.M.; Weller, P.F. Eosinophil extracellular DNA trap cell death mediates lytic release of free secretion-competent eosinophil granules in humans. Blood 2013, 121, 2074-2083. [CrossRef] [PubMed]

172. Choi, Y.; Le Pham, D.; Lee, D.H.; Lee, S.H.; Kim, S.H.; Park, H.S. Biological function of eosinophil extracellular traps in patients with severe eosinophilic asthma. Exp. Mol. Med. 2018, 50, 104. [CrossRef] [PubMed]

173. Mahmudi-Azer, S.; Downey, G.P.; Moqbel, R. Translocation of the tetraspanin CD63 in association with human eosinophil mediator release. Blood 2002, 99, 4039-4047. [CrossRef] [PubMed]

174. Akuthota, P.; Melo, R.C.N.; Spencer, L.A.; Weller, P.F. MHC class II and CD9 in human eosinophils localize to detergent-resistant membrane microdomains. Am. J. Respir. Cell Mol. Biol. 2012, 46, 188-195. [CrossRef]

175. Muniz, V.S.; Weller, P.F.; Neves, J.S. Eosinophil crystalloid granules: Structure, function, and beyond. J. Leukoc. Biol. 2012, 92, 281-288. [CrossRef]

176. Akuthota, P.; Carmo, L.A.S.; Bonjour, K.; Murphy, R.O.; Silva, T.P.; Gamalier, J.P.; Capron, K.L.; Tigges, J.; Toxavidis, V.; Camacho, V.; et al. Extracellular microvesicle production by human eosinophils activated by "inflammatory" stimuli. Front. Cell Dev. Biol. 2016, 4, 117. [CrossRef]

177. Cañas, J.A.; Sastre, B.; Mazzeo, C.; Fernández-Nieto, M.; Rodrigo-Muñoz, J.M.; González-Guerra, A.; Izquierdo, M.; Barranco, P.; Quirce, S.; Sastre, J.; et al. Exosomes from eosinophils autoregulate and promote eosinophil functions. J. Leukoc. Biol. 2017, 101, 1191-1199. [CrossRef]

178. Li, W.; Gao, P.; Zhi, Y.; Xu, W.; Wu, Y.; Yin, J.; Zhang, J. Periostin: Its role in asthma and its potential as a diagnostic or therapeutic target. Respir. Res. 2015, 16, 57. [CrossRef]

179. Barthel, S.R.; Johansson, M.W.; McNamee, D.M.; Mosher, D.F. Roles of integrin activation in eosinophil function and the eosinophilic inflammation of asthma. J. Leukoc. Biol. 2008, 83, 1-12. [CrossRef]

180. Xin, J.; Sun, H.; Kong, H.; Li, L.; Zheng, J.; Yin, C.; Cao, Y.; Jia, Y.; Li, C. Intercellular adhesion molecule-1 expression in activated eosinophils is associated with mucosal remodeling in nasal polyps. Mol. Med. Rep. 2015, 11, 3391-3397. [CrossRef]

181. Borish, L. The immunology of asthma: Asthma phenotypes and their implications for personalized treatment. Ann. Allergy Asthma Immunol. 2016, 117, 108-114. [CrossRef] [PubMed]

182. Wirz, O.F.; Głobińska, A.; Ochsner, U.; van de Veen, W.; Eller, E.; Christiansen, E.S.; Halken, S.; Nielsen, C.; Bindslev-Jensen, C.; Antó, J.M.; et al. Comparison of regulatory B cells in asthma and allergic rhinitis. Allergy Eur. J. Allergy Clin. Immunol. 2019, 74, 815-818. [CrossRef] [PubMed]

183. Ventimiglia, L.N.; Alonso, M.A. Biogenesis and function of T cell-derived exosomes. Front. Cell Dev. Biol. 2016, 4, 84. [CrossRef] [PubMed]

184. Shefler, I.; Salamon, P.; Levi-Schaffer, F.; Mor, A.; Hershko, A.Y.; Mekori, Y.A. MicroRNA-4443 regulates mast cell activation by T cell-derived microvesicles. J. Allergy Clin. Immunol. 2018, 141, 2132-2141.e4. [CrossRef] [PubMed]

185. Shefler, I.; Salamon, P.; Reshef, T.; Mor, A.; Mekori, Y.A. T Cell-Induced Mast Cell Activation: A Role for Microparticles Released from Activated T Cells. J. Immunol. 2010, 185, 4206-4212. [CrossRef] [PubMed]

186. Admyre, C.; Bohle, B.; Johansson, S.M.; Focke-Tejkl, M.; Valenta, R.; Scheynius, A.; Gabrielsson, S. B cell-derived exosomes can present allergen peptides and activate allergen-specific T cells to proliferate and produce TH2-like cytokines. J. Allergy Clin. Immunol. 2007, 120, 1418-1424. [CrossRef]

187. Almqvist, N.; Lönnqvist, A.; Hultkrantz, S.; Rask, C.; Telemo, E. Serum-derived exosomes from antigen-fed mice prevent allergic sensitization in a model of allergic asthma. Immunology 2008, 125, 21-27. [CrossRef]

188. Barnes, P.J. Immunology of asthma and chronic obstructive pulmonary disease. Nat. Rev. Immunol. 2008, 8, 183-192. [CrossRef]

189. Mills, C.D.; Kincaid, K.; Alt, J.M.; Heilman, M.J.; Hill, A.M. M-1/M-2 Macrophages and the Th1/Th2 Paradigm. J. Immunol. 2000, 164, 6166-6173. [CrossRef]

190. Ismail, N.; Wang, Y.; Dakhlallah, D.; Moldovan, L.; Agarwal, K.; Batte, K.; Shah, P.; Wisler, J.; Eubank, T.D.; Tridandapani, S.; et al. Macrophage microvesicles induce macrophage differentiation and miR-223 transfer. Blood 2013, 121, 984-995. [CrossRef]

191. Nagano, T.; Katsurada, M.; Dokuni, R.; Hazama, D.; Kiriu, T.; Umezawa, K.; Kobayashi, K.; Nishimura, Y. Crucial Role of Extracellular Vesicles in Bronchial Asthma. Int. J. Mol. Sci. 2019, 20, 2589. [CrossRef] [PubMed] 
192. Esser, J.; Gehrmann, U.; D'Alexandri, F.L.; Hidalgo-Estévez, A.M.; Wheelock, C.E.; Scheynius, A.; Gabrielsson, S.; Rdmark, O. Exosomes from human macrophages and dendritic cells contain enzymes for leukotriene biosynthesis and promote granulocyte migration. J. Allergy Clin. Immunol. 2010, 126, 1032-1040. [CrossRef] [PubMed]

193. Pei, W.; Zhang, Y.; Li, X.; Luo, M.; Chen, T.; Zhang, M.; Zhong, M.; Lv, K. LncRNA AK085865 depletion ameliorates asthmatic airway inflammation by modulating macrophage polarization. Int. Immunopharmacol. 2020, 83, 106450. [CrossRef] [PubMed]

194. Korošec, P.; Gibbs, B.F.; Rijavec, M.; Custovic, A.; Turner, P.J. Important and specific role for basophils in acute allergic reactions . Clin. Exp. Allergy 2018, 48, 502-512. [CrossRef] [PubMed]

195. Davis, K.U.; Sheats, M.K. The Role of Neutrophils in the Pathophysiology of Asthma in Humans and Horses. Inflammation 2020, in press. [CrossRef] [PubMed]

196. Seys, S.F.; Lokwani, R.; Simpson, J.L.; Bullens, D.M.A. New insights in neutrophilic asthma. Curr. Opin. Pulm. Med. 2019, 25, 113-120. [CrossRef] [PubMed]

197. Vargas, A.; Roux-Dalvai, F.; Droit, A.; Lavoie, J.P. Neutrophil-derived exosomes: A new mechanism contributing to airway smooth muscle remodeling. Am. J. Respir. Cell. Mol. Biol. 2016, 55, 450-461. [CrossRef]

198. Butin-Israeli, V.; Houser, M.C.; Feng, M.; Thorp, E.B.; Nusrat, A.; Parkos, C.A.; Sumagin, R. Deposition of microparticles by neutrophils onto inflamed epithelium: A new mechanism to disrupt epithelial intercellular adhesions and promote transepithelial migration. FASEB J. 2016, 30, 4007-4020. [CrossRef]

199. Genschmer, K.R.; Russell, D.W.; Lal, C.; Szul, T.; Bratcher, P.E.; Noerager, B.D.; Abdul Roda, M.; Xu, X.; Rezonzew, G.; Viera, L.; et al. Activated PMN Exosomes: Pathogenic Entities Causing Matrix Destruction and Disease in the Lung. Cell 2019, 176, 113-126.e15. [CrossRef]

200. Merluzzi, S.; Betto, E.; Ceccaroni, A.A.; Magris, R.; Giunta, M.; Mion, F. Mast cells, basophils and B cell connection network. Mol. Immunol. 2015, 63, 94-103. [CrossRef]

201. Lecce, M.; Molfetta, R.; Milito, N.D.; Santoni, A.; Paolini, R. Fceri signaling in the modulation of allergic response: Role of mast cell-derived exosomes. Int. J. Mol. Sci. 2020, 21, 5464. [CrossRef] [PubMed]

202. Xia, Y.C.; Harris, T.; Stewart, A.G.; MacKay, G.A. Secreted factors from human mast cells trigger inflammatory cytokine production by human airway smooth muscle cells. Int. Arch. Allergy Immunol. 2012, 160, 75-85. [CrossRef] [PubMed]

203. Tkaczyk, C.; Villa, I.; Peronet, R.; David, B.; Chouaib, S.; Mécheri, S. In vitro and in vivo immunostimulatory potential of bone marrow-derived mast cells on b- and T-lymphocyte activation. J. Allergy Clin. Immunol. 2000, 105, 134-142. [CrossRef]

204. Xie, G.; Yang, H.; Peng, X.; Lin, L.; Wang, J.; Lin, K.; Cui, Z.; Li, J.; Xiao, H.; Liang, Y.; et al. Mast cell exosomes can suppress allergic reactions by binding to IgE. J. Allergy Clin. Immunol. 2018, 141, 788-791. [CrossRef] [PubMed]

205. Stone, K.D.; Prussin, C.; Metcalfe, D.D. IgE, mast cells, basophils, and eosinophils. J. Allergy Clin. Immunol. 2010, 125, 73-80. [CrossRef]

206. Dvorak, A.M. Degranulation and recovery from degranulation of basophils and mast cells. Chem. Immunol. Allergy 2005, 85, 205-251. [CrossRef]

207. Kulshreshtha, A.; Ahmad, T.; Agrawal, A.; Ghosh, B. Proinflammatory role of epithelial cell-derived exosomes in allergic airway inflammation. J. Allergy Clin. Immunol. 2013, 131, 1194-1203. [CrossRef]

208. Ax, E.; Ax, E.; Jevnikar, Z.; Cvjetkovic, A.; Malmhäll, C.; Olsson, H.; Rådinger, M.; Lässer, C. T2 and T17 cytokines alter the cargo and function of airway epithelium-derived extracellular vesicles. Respir. Res. 2020, 21, 155. [CrossRef]

209. Duarte, D.; Taveira-Gomes, T.; Sokhatska, O.; Palmares, C.; Costa, R.; Negrão, R.; Guimarães, J.T.; Delgado, L.; Soares, R.; Moreira, A. Increased circulating platelet microparticles as a potential biomarker in asthma. Allergy Eur. J. Allergy Clin. Immunol. 2013, 68, 1073-1075. [CrossRef]

210. Kornerup, K.N.; Page, C.P. The role of platelets in the pathophysiology of asthma. Platelets 2007, 18, 319-328. [CrossRef]

211. Yan, Z.; Zhuansun, Y.; Chen, R.; Li, J.; Ran, P. Immunomodulation of mesenchymal stromal cells on regulatory T cells and its possible mechanism. Exp. Cell Res. 2014, 324, 65-74. [CrossRef] [PubMed]

212. Li, H.; Tian, Y.; Xie, L.; Liu, X.; Huang, Z.; Su, W. Mesenchymal stem cells in allergic diseases: Current status. Allergol. Int. 2020, 69, 35-45. [CrossRef] [PubMed]

213. Du, Y.M.; Zhuansun, Y.X.; Chen, R.; Lin, L.; Lin, Y.; Li, J.G. Mesenchymal stem cell exosomes promote immunosuppression of regulatory T cells in asthma. Exp. Cell Res. 2018, 363, 114-120. [CrossRef] [PubMed]

214. Harrell, C.R.; Simovic Markovic, B.; Fellabaum, C.; Arsenijevic, A.; Djonov, V.; Arsenijevic, N.; Volarevic, V. Therapeutic potential of mesenchymal stem cell-derived exosomes in the treatment of eye diseases. Adv. Exp. Med. Biol. 2018, 1089, 47-57. [CrossRef] [PubMed]

215. Guo, L.; Lai, P.; Wang, Y.; Huang, T.; Chen, X.; Luo, C.; Geng, S.; Huang, X.; Wu, S.; Ling, W.; et al. Extracellular vesicles from mesenchymal stem cells prevent contact hypersensitivity through the suppression of Tc1 and Th1 cells and expansion of regulatory T cells. Int. Immunopharmacol. 2019, 74, 105663. [CrossRef] [PubMed]

216. Nojehdehi, S.; Soudi, S.; Hesampour, A.; Rasouli, S.; Soleimani, M.; Hashemi, S.M. Immunomodulatory effects of mesenchymal stem cell-derived exosomes on experimental type-1 autoimmune diabetes. J. Cell. Biochem. 2018, 119, 9433-9443. [CrossRef]

217. Tamura, R.; Uemoto, S.; Tabata, Y. Immunosuppressive effect of mesenchymal stem cell-derived exosomes on a concanavalin A-induced liver injury model. Inflamm. Regen. 2016, 36, 26. [CrossRef] 
218. Riazifar, M.; Mohammadi, M.R.; Pone, E.J.; Yeri, A.; Lasser, C.; Segaliny, A.I.; McIntyre, L.L.; Shelke, G.V.; Hutchins, E.; Hamamoto, A.; et al. Stem Cell-Derived Exosomes as Nanotherapeutics for Autoimmune and Neurodegenerative Disorders. ACS Nano 2019, 13, 6670-6688. [CrossRef]

219. Shahir, M.; Mahmoud Hashemi, S.; Asadirad, A.; Varahram, M.; Kazempour-Dizaji, M.; Folkerts, G.; Garssen, J.; Adcock, I.; Mortaz, E. Effect of mesenchymal stem cell-derived exosomes on the induction of mouse tolerogenic dendritic cells. J. Cell. Physiol. 2020, 235, 7043-7055. [CrossRef]

220. Fang, S.B.; Zhang, H.Y.; Wang, C.; He, B.X.; Liu, X.Q.; Meng, X.C.; Peng, Y.Q.; Xu, Z.B.; Fan, X.L.; Wu, Z.J.; et al. Small extracellular vesicles derived from human mesenchymal stromal cells prevent group 2 innate lymphoid cell-dominant allergic airway inflammation through delivery of miR-146a-5p. J. Extracell. Vesicles 2020, 9, 1723260. [CrossRef]

221. Elahi, F.M.; Farwell, D.G.; Nolta, J.A.; Anderson, J.D. Preclinical translation of exosomes derived from mesenchymal stem/stromal cells. Stem Cells 2020, 38, 15-21. [CrossRef] [PubMed]

222. Yu, X.; Yu, L.; Guo, B.; Chen, R.; Qiu, C. A narrative review of research advances in mesenchymal stem cell therapy for asthma. Ann. Transl. Med. 2020, 8, 1461. [CrossRef] [PubMed]

223. Porro, C.; Lepore, S.; Trotta, T.; Castellani, S.; Ratclif, L.; Battaglino, A.; Di Gioia, S.; Martínez, M.C.; Conese, M.; Maffione, A.B. Isolation and characterization of microparticles in sputum from cystic fibrosis patients. Respir. Res. 2010, 11, 94. [CrossRef] [PubMed]

224. Dai, R.; Liu, J.; Cai, S.; Zheng, C.; Zhou, X. Delivery of adipose-derived mesenchymal stem cells attenuates airway responsiveness and inflammation in a mouse model of ovalbumin-induced asthma. Am. J. Transl. Res. 2017, 9, 2421-2428. 